\title{
高強度コンクリートの初期温度上昇と設計基準強度の関係 及びその調合強度への影響について \\ RELATION BETWEEN EARLY STAGE HYDRATION HEAT OF CEMENT AND LATER AGE STRUCTURAL STRENGTH AND ITS INFLUENCE ON TARGET STRENGTH
}

\author{
戸祭邦之* \\ Kuniyuki TOMATSURI
}

\begin{abstract}
The relatively long term structural strength of high strength concrete may depend on the magnitude of temperature inside the structure during the early stage of hydration of cement. The effect of early heat of hydration and the size of the structural member on the structural strength is discussed here. The target strength for designing concrete mixture under high hydration heat which hurts the strength gain of the structure is also discussed.
\end{abstract}

Keywords : hydration heat, high strength concrete, structural strength, designing of concrete mixture 水和発熱, 高強度コンクリート, 構造体強度, 調合計画

\section{はじめに}

日本建築学会建築工事標準仕様書 JASS 5 鉄筋コンク リート工事（以降JASS 5 という）に述べられている構 造体コンクリート圧縮強度（以降構造体コンクリート圧 縮強度を単に構造体強度という）に関する品質管理と調 合強度決定法とを比較の対象としながら，筆者は，設計 基準強度 $360 \mathrm{kgf} / \mathrm{cm}^{2}$ を超える高強度コンクリートの調 合強度決定法について, 本誌にこれまで何回か記述した。 本誌 419 号「設計基準強度 $360 \mathrm{kgf} / \mathrm{cm}^{2}$ 以上の高強度コ ンクリートの調合設計における気温補正について」”に は，構造体強度の管理材令を積算温度 $1365^{\circ} \mathrm{D} \cdot \mathrm{D}$ を満 足するような中長期材令にとれば，気温補正は必要では ないことを述べ，本誌 429 号「中長期の強度伸展を考慮 した高強度コンクリートの調合計画に関する一考察」21 には，積算温度と強度発現の関係をベースにした設計基 準強度 $360 \mathrm{kgf} / \mathrm{cm}^{2}$ を超える高強度コンクリートの調合 計画の方法を示した。本誌 445 号「水和発熱による高温

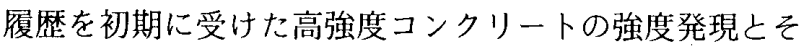

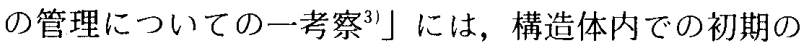
水和発熱による温度の上昇が大きい場合には, 中長期域 の構造体強度発現は影響を受け, 温度上昇の大きさに応 じて, 構造体強度発現の停滞が起こることを示した。ま た, 本誌 449 号「高強度コンクリートにおける各種養生
供試体強度とコア供試体強度の関係について」では, 同一コンクリートの強度評価に標準養生供試体強度, 現 場封縅養生供試体強度, 構造体強度 (コア供試体強度) の 3 種類の強度を適用すると, 同一積算温度でそれら 3 種類の強度を比較した場合でも，それぞれに，1割前後 のそごを生じることを述べ，そのため構造体強度の管理 としてはストレートにコア供試体強度で評価した方がよ いが，簡単にはその方法を決めにくいことから，とりあ えずは標準養生供試体強度での評価に統一するのがよい のではないか, ということを提案した。

今回は, そのあとをうけて, 構造体内初期温度上昇と 設計基準強度の関係, 及びその関係もふまえて標準養生 供試体強度を構造体強度管理に用いる場合の調合強度と 設計基準強度の関係について述べるものである。

\section{1. 構造体内初期温度上昇と設計基準強度}

初期の水和発熱による温度の上昇によって, 中長期域 の構造体強度（コア供試体強度）発現は影響を受ける。 調合計画を行う場合には，あらかじめ温度上昇の予測を する必要がある。初期の水和発熱による構造体内部の温 度上昇は, 構造体内で最も温度上昇が大きいと考えられ る中心部で経験した最も高い温度を最高到達温度, その 最高到達温度と打設直前のコンクリート温度との差を温 
度上昇量とすると，最高到達温度で $70^{\circ} \mathrm{C}$ 以上，または 温度上昇量で $40^{\circ} \mathrm{C}$ 以上の場合には中長期域の構造体強 度発現は大きく影響を受ける。それ以下の温度では影響 が比較的小さい方から，スラブや壁のような薄い部材は ほぼ影響を受けないとみなせる。構造体強度発現に大き く影響があると予想されるのは柱や梁である。そのうち 梁については, 初期水和発熱による温度上昇が大きそう なのは特に断面の大きい地中梁のような場合である。し かし，地中梁は高層鉄筋コンクリート造の場合でも，そ れほぼ高強度を必要とするわけではない。高強度コンク リートの適用ということを考えると，ほとんど垂直部材 としての柱が主体になると考えられる。そこで，本論文 では柱を想定した初期水和発熱による温度上昇の予测計 算を行い，平均気温や水セメント比との関連で，構造体 がよ゙のような上昇温度になるかについて検討を行う。

1.1 計算に使用するプログラム

構造体内部の初期の温度上昇を予測する計算を行うプ ログラムはいくつかあるが，パソコンで簡単に行えるも のが便利である。ここでは，マスコンクリートの温度ひ び割れ検討用に開発され，一般に市販されているプログ ラム名 MASPAを使用する。使用する電算の機種は NEC/PC-9800 シリーズである。この MASPAを使用 するに際して，実測值との比較を行った。表一1および

表一1 MASPAによる予測計算（測定值との比較）

\begin{tabular}{|c|c|c|c|c|c|c|c|c|}
\hline \multirow{2}{*}{$\begin{array}{l}\text { 実 } \\
\text { 鈳 }\end{array}$} & \multirow{2}{*}{$\begin{array}{l}\text { 水セx } \\
\text { ント此 } \\
\text { (\%) }\end{array}$} & \multirow{2}{*}{$\begin{array}{l}\text { 単位セメ } \\
\text { ント量 } \\
\left(\mathrm{kg} / \mathrm{m}^{3}\right)\end{array}$} & \multirow{2}{*}{$\begin{array}{l}\text { 気 温 } \\
\left({ }^{\circ} \mathrm{C}\right)\end{array}$} & \multirow{2}{*}{$\begin{array}{l}\text { コンクリ } \\
\text {-ト温度 } \\
\left({ }^{\circ} \mathrm{C}\right)\end{array}$} & \multicolumn{3}{|c|}{ 最商到達温度 $\left({ }^{\circ} \mathrm{C}\right)$} & \multirow{2}{*}{$\begin{array}{l}\text { 試呀体の } \\
\text { 大きさ (m) }\end{array}$} \\
\hline & & & & & 測定值 & 計算値 & 差 & \\
\hline 1 & 28 & 589 & $\begin{array}{r}28 \\
18 \\
7\end{array}$ & $\begin{array}{l}35 \\
27 \\
17\end{array}$ & $\begin{array}{l}81 \\
70 \\
54\end{array}$ & $\begin{array}{l}75 \\
64 \\
47\end{array}$ & $\begin{array}{l}6 \\
6 \\
7\end{array}$ & $\begin{array}{l}0.8 \times 0.8 \\
\times 1.8\end{array}$ \\
\hline 口 & 28.5 & 561 & 34 & 34 & 78 & 77 & 1 & $\begin{array}{l}0.8 \times 0.8 \\
\times 0.95\end{array}$ \\
\hline 八 & $\begin{array}{l}27.0 \\
28.5\end{array}$ & $\begin{array}{l}574 \\
544\end{array}$ & $\begin{array}{l}33 \\
33\end{array}$ & $\begin{array}{l}38 \\
39.5\end{array}$ & $\begin{array}{l}90 \\
88\end{array}$ & $\begin{array}{l}87 \\
86\end{array}$ & $\begin{array}{l}3 \\
2\end{array}$ & $\begin{array}{l}1.1 \times 1.1 \\
\times 3.0\end{array}$ \\
\hline$=$ & $\begin{array}{l}26 \\
28\end{array}$ & $\begin{array}{l}577 \\
536\end{array}$ & $\begin{array}{l}33 \\
34\end{array}$ & $\begin{array}{l}38 \\
35 .\end{array}$ & $\begin{array}{l}84 \\
77\end{array}$ & $\begin{array}{l}80 \\
75\end{array}$ & $\begin{array}{l}4 \\
2\end{array}$ & $\begin{array}{l}0.85 \times 0.85 \\
\times 1.00\end{array}$ \\
\hline
\end{tabular}

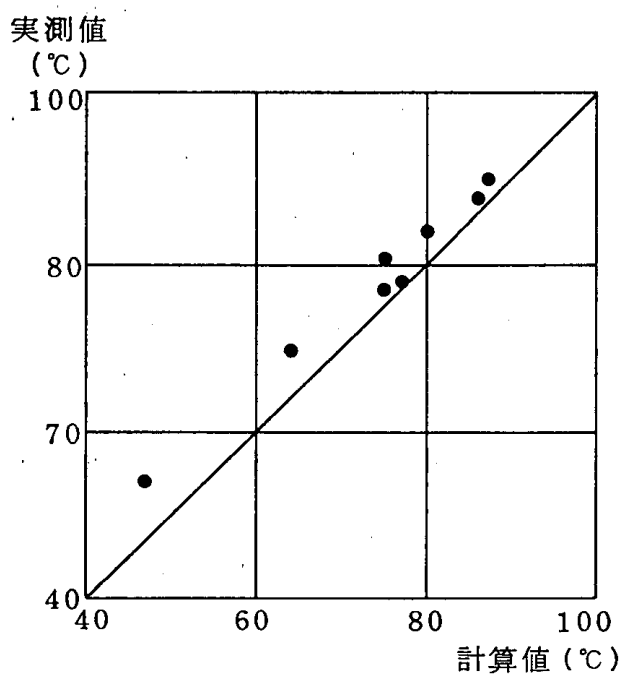

図一1計算値と実測值比較（MASPAによる)
図一1である。実験（イ）の実測值と計算值の差は6〜 $7^{\circ} \mathrm{C}$ と大きく, その他の実験の差は $1 \sim 4^{\circ} \mathrm{C}$ と比較的低 く納まっている。それは，MASPAのプログラムには， セメントの断熱温度上昇式の実験定数として, 経験上の 平均的な值が入力されていると考えられるが，現在販売 されているセメントの中には，この実験定数が経験的平 均值と少し違う值を持つものがあるから，その差が実測 值と計算值の差となって表われたと考えられる。した がって，この程度の実測値と計算值の差はやむを得ず, 一般的な予測計算をする上において差し支えのない精度 であると判断する。

\section{2 柱の大きさ, 外気温と初期構造体温度の関係}

構造体内部の初期水和発熱による温度上昇は柱の大き さや外気温などの影響を受ける。柱の大きさとしては, 大体経験的な大きさから断面寸法が $800 \sim 1100 \mathrm{~mm}$ 程 度と考え, $900 \times 900 \mathrm{~mm}$ と $1100 \times 1100 \mathrm{~mm}$ の 2 種類の 断面寸法を選ぶ。外気温は $5^{\circ} \mathrm{C}$ ぎんに，15，20, 25 及 び $30^{\circ} \mathrm{C}$ の 4 水準とする。コンクリートの調合について は, 水セメント水比で $25 \%$ - $50 \%$, セメント水比で 2.0〜4.0の範囲を想定し, その間で 3 （一部 7 または 4) 水準を選ぶ。その際，単位水量（スランプ 18〜24 cm) を経験的に $155 \sim 175 l$ と考え, $155 l$ と $175 l$ の 2 種類 を選んで単位セメント量を計算する。また，外気温とコ ンクリート温度の差については，これも経験上水セメン ト比が小さいほど大きいので, 水セメント比 $25 \%$ 前後 のときの外気温とコンクリート温度の差が $10^{\circ} \mathrm{C}$ 程度に なり，水セメント比 $50 \%$ 程度では $5^{\circ} \mathrm{C}$ になるとを考 慮し, その 2 つの值をもとに水セメント比に応じた值を 設定する。

表一2は，計算の条件とその条件を与えたときの MASPAによる構造体内部の温度上昇予測計算結果で

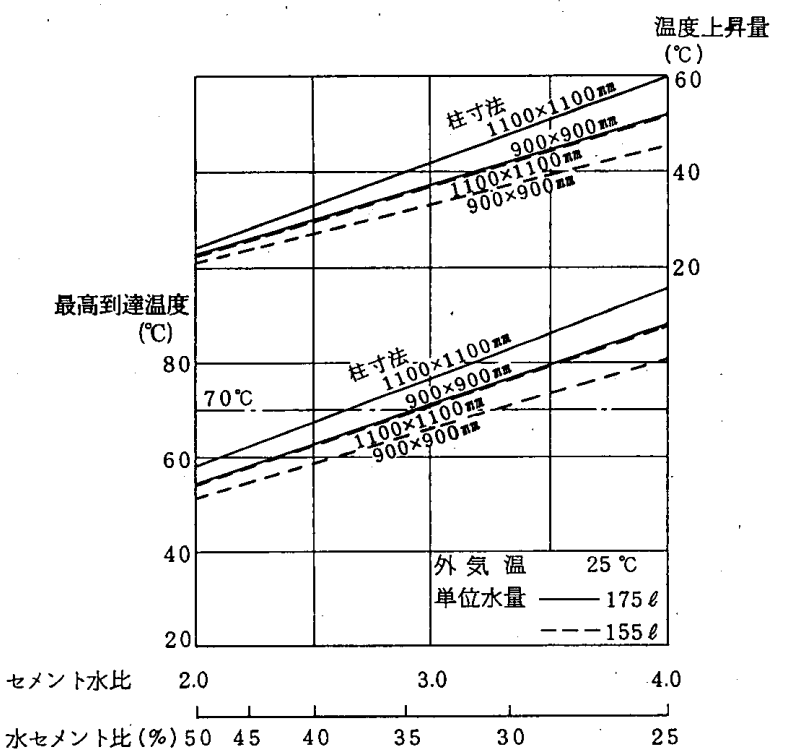

図一2 外気温 $25^{\circ} \mathrm{C}$ のときの初期の温度上昇予測比較（柱モデ ル) 
ある。その予測計算結果をグラフに表したのが図一 2 , 図一 3 である。いずれの場合も下半分のグラフが最高到 達温度を表し左の目盛を使用する。上半分のグラフは, 温度上昇量であり右の目盛で表している。図一2は外気 温を $25^{\circ} \mathrm{C}$ の一定にしたときの構造体温度と柱断面寸法 及び単位水量との関係を表した図で, 図一3.は柱断面寸 法 $900 \times 900 \mathrm{~mm}, 1100 \times 1100 \mathrm{~mm}$ それぞれについて単 位セメント量と構造体内温度との関係を示すグラフであ る。

図一 2 と図一 3 とを比較すると, 構造体内の上昇温度 は外気温度の影響が大きく，それに比べると柱断面寸法 と単位水量の影響は小さい。図一 2 によると, 柱断面寸 法 $200 \mathrm{~mm}$ の差による構造体内温度への影響と単位水量 $20 l$ の調合差が構造体温度へ与える影響はほぼ同じであ る。いま, 中長期域の構造体強度発現が影響を受けない
初期の温度条件として, 最高到達温度 $70^{\circ} \mathrm{C}$ 以下, また は温度上昇量 $40^{\circ} \mathrm{C}$ 以下を考える。その場合, 図一3 上り, 外気温が高く20 $25^{\circ} \mathrm{C}$ のときは最高到達温度 $70^{\circ} \mathrm{C}$ 以 下の条件の方が温度上昇量 $40^{\circ} \mathrm{C}$ 以下の条件上り優先 し, 外気温が低く $15^{\circ} \mathrm{C}$ 以下の場合には温度上昇量 $40^{\circ} \mathrm{C}$ 以下の条件の方が優先適用されることが分かる。 しかし, 外気温が $15^{\circ} \mathrm{C}$ 以下の場合でも, 最高到達温度 $70^{\circ} \mathrm{C}$ 以下の条件と温度上昇量 $40^{\circ} \mathrm{C}$ 以下の条件に，そ れほど大きな違いがあるわけではなく, 最高到達温度 $70^{\circ} \mathrm{C}$ 以下の条件で, 温度上昇量 $40^{\circ} \mathrm{C}$ 以下の条件を代 表しても，大体の傾向を論ずる場合には差し支えないと 考えられる。

水和初期の構造体温度の上昇に外気温が影響を与える のはコンクリートを打設してから 3 ，4 日長くても7日 間である。丸善発行の理科年表に気温の半旬別平均值が

表一2 MASPAによる予測計算（柱モデル）

\begin{tabular}{|c|c|c|c|c|c|c|c|c|c|c|c|c|c|c|c|c|c|}
\hline \multirow{2}{*}{\multicolumn{4}{|c|}{\begin{tabular}{|c|} 
与 条 件 項 ${ }^{\text {目 }}$ \\
外気温とコンクリート温度 \\
の差 ( $\left.{ }^{\circ} \mathrm{C}\right)$
\end{tabular}}} & \multicolumn{7}{|c|}{ 最高到達温度 $\left({ }^{\circ} \mathrm{C}\right)$} & \multicolumn{7}{|c|}{ 温度上昇量 $\left({ }^{\circ} \mathrm{C}\right)$} \\
\hline & & & & +10 & +10 & +9 & +8 & +7 & +6 & +5 & \multicolumn{3}{|c|}{$+10 \mid+9$} & +8 & +7 & +6 & +5 \\
\hline \multirow{2}{*}{\multicolumn{4}{|c|}{$\begin{array}{l}\text { セメント水比 } \\
\text { 水セメント比 }(\%)\end{array}$}} & \multirow{2}{*}{$\begin{array}{r}4.00 \\
25.0 \\
\end{array}$} & \multirow{2}{*}{$\begin{array}{r}3.70 \\
27.0 \\
\end{array}$} & \multirow{2}{*}{\begin{tabular}{|c|}
3.33 \\
30.0 \\
\end{tabular}} & \multirow{2}{*}{$\begin{array}{r}3.00 \\
33.3 \\
\end{array}$} & \multirow{2}{*}{$\begin{array}{r}2.70 \\
37.0 \\
\end{array}$} & \multirow{2}{*}{\begin{tabular}{|r|}
2.30 \\
43.5 \\
\end{tabular}} & \multirow{2}{*}{$\begin{array}{r}2.00 \\
50.0 \\
\end{array}$} & \multirow{2}{*}{$\begin{array}{r}4.00 \\
25.0\end{array}$} & \multirow{2}{*}{$\begin{array}{r}3.70 \\
27.0 \\
\end{array}$} & \multirow{2}{*}{$\begin{array}{r}3.33 \\
30.0 \\
\end{array}$} & \multirow{2}{*}{$\begin{array}{r}3.00 \\
33.3\end{array}$} & \multirow{2}{*}{$\begin{array}{r}2.70 \\
37.0\end{array}$} & \multirow{2}{*}{$\begin{array}{r}2.30 \\
43.5\end{array}$} & \\
\hline & & & & & & & & & & & & & & & & & 50.0 \\
\hline \multirow{9}{*}{$\begin{array}{c}\text { 単 } \\
\text { 位 } \\
\text { 水 } \\
\text { 量 } \\
175 !\end{array}$} & 単位t & メント量 & (kg) & 700 & 648 & 583 & 526 & 473 & 402 & 350 & 700 & 648 & 583 & $\frac{00.0}{526}$ & 473 & 402 & $\frac{00.0}{350}$ \\
\hline & 柱 & 外気温 & $30^{\circ} \mathrm{C}$ & 94 & 89 & 83 & 77 & 71.5 & 65 & 60.5 & 54 & 49 & 44 & 39 & 34.5 & 29 & 25.5 \\
\hline & 900 & & $25^{\circ} \mathrm{C}$ & 88 & 83 & 77 & 71 & 66 & 59 & 54 & 53 & 48 & 43 & 38 & 33 & 28 & 24 \\
\hline & $x$ & & $20^{\circ} \mathrm{C}$ & 81 & 77 & 70 & 64. & 59 & 52 & 47.5 & 51 & 47 & 41 & 36 & 32 & 26 & 22.5 \\
\hline & $900 \mathrm{~mm}$ & & $15^{\circ} \mathrm{C}$ & 74 & 70 & 63 & 57 & 52 & 45 & 40 & 49 & 45 & 39 & 34 & 30 & 24 & 20 \\
\hline & 柱 & 外気温 & $30^{\circ} \mathrm{C}$ & 100 & 95 & & 82 & & & 65 & 60 & 55 & & 44 & & & 30 \\
\hline & 11100 & & $25^{\circ} \mathrm{C}$ & 94.5 & 90 & & 77 & & & 58 & 59.5 & 55 & & 44 & & & 28 \\
\hline & $\times$ & & $20^{\circ} \mathrm{C}$ & 88 & 83.5 & & 70 & & & 52 & 58 & 53.5 & & 42 & & & 27 \\
\hline & $1100 \mathrm{~mm}$ & & $15^{\circ} \mathrm{C}$ & 81 & 77 & & 63 & & & 45 & 56 & 52 & & 40 & & & 25 \\
\hline \multirow{9}{*}{$\begin{array}{c}\text { 単 } \\
\text { 位 } \\
\text { 水 } \\
\text { 量 } \\
155 \downarrow\end{array}$} & 単位七 & メント血 & 量 $(\mathrm{kg})$ & 620 & 574 & 517 & 465 & 419 & 356 & 310 & 620 & 574 & 517 & 465 & 419 & 356 & 310 \\
\hline & 柱 & 外気温 & $30^{\circ} \mathrm{C}$ & & 83 & & 72 & & & 57.5 & & 43 & & 34 & & & 22.5 \\
\hline & 900 & & $25^{\circ} \mathrm{C}$ & & 77 & & 66 & & & 51.5 & & 42 & & 33 & & & 21.5 \\
\hline & $x$ & & $20^{\circ} \mathrm{C}$ & & 70 & & 60 & & & 45 & & 40 & & 32 & & & 20 \\
\hline & $900 \mathrm{~mm}$ & & $15^{\circ} \mathrm{C}$ & & 63 & & 52 & & & 37.5 & & 38 & & 29 & & & 17.5 \\
\hline & 柱 & 外気温 & $30^{\circ} \mathrm{C}$ & & 89 & & 77 & & & 62 & & 49 & & 39 & & & 27 \\
\hline & 1100 & & $25^{\circ} \mathrm{C}$ & & 83 & & 71 & & & 55 & & 48 & & 38 & & & 25 \\
\hline & $x$ & & $20^{\circ} \mathrm{C}$ & & 77 & & 65 & & & 49 & & 47 & & 37 & & & 24 \\
\hline & $1100 \mathrm{~mm}$ & & $15^{\circ} \mathrm{C}$ & & 70 & & 57.5 & & & 42 & & 45 & & 34.5 & & & 22 \\
\hline
\end{tabular}
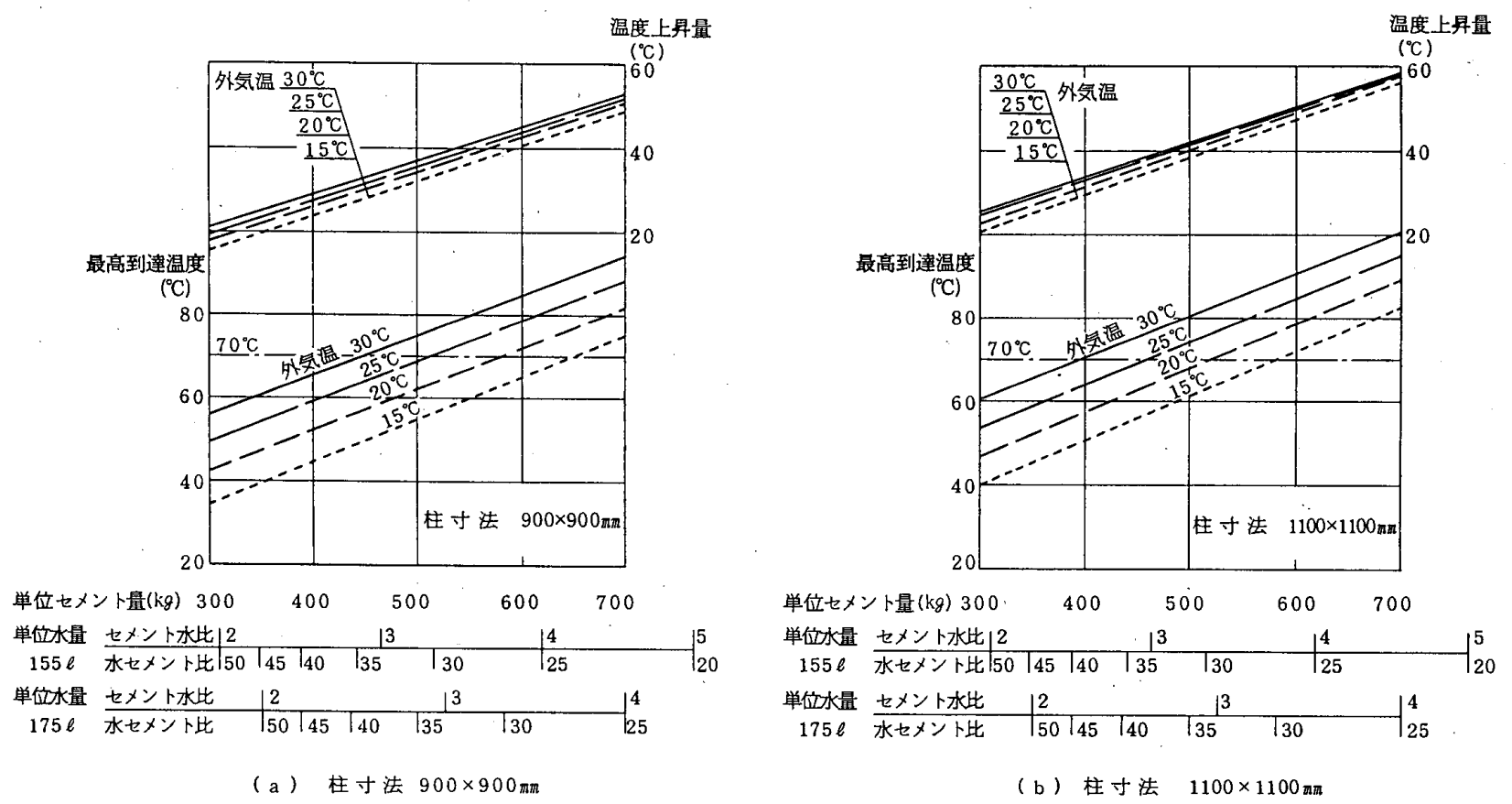

图一3 単位セメント量と初期の温度上昇予測（柱モデル） 
記載されているが,この值がほぼその外気温に相当する。 昭和 64 年版でみると気温の半旬別平均値が $28^{\circ} \mathrm{C}$.を超 えるのは, 大阪, 福岡, 鹿児島及び那覇の一部の期間で あり，その場合でも $29^{\circ} \mathrm{C}$ は超えていない。他はすべて $28^{\circ} \mathrm{C}$ 末満である。したがって，日本国内では 1 日だけ の平均気温が $30^{\circ} \mathrm{C}$ になるこ法あるが，沖縄を含めて 5 日間を平均した場合には，一部の例外を除きほぼ外気 温 $28^{\circ} \mathrm{C}$ が最高であるとみなせる。そこで，図一3 から 外気温 $28^{\circ} \mathrm{C}$ のとき構造体内温度が最高到達温度で $70^{\circ} \mathrm{C}$ 以下，または温度上昇量で $40^{\circ} \mathrm{C}$ 以下の条件を満 足するときのセメント水比を求める。単位水量が $155 l$ の場合, 柱断面寸法 $900 \times 900 \mathrm{~mm}$ では, セメント水比 3.0 以下, 柱断面寸法 $1100 \times 1100 \mathrm{~m}$ ではセメント水比 2.7 以下である。水セメント比では $33.3 \%$ 以上， 37.0 $\%$ 以上となる。単位水量が、175lの場合では柱断面寸法 $900 \times 900 \mathrm{~mm}$ の場合がセメント水比 2.7 以下（水七メ ント比 $37.0 \%$ 以上)，柱断面寸法 $1100 \times 1100 \mathrm{~mm}$ の 場合はセメント水比 2.4 以下（水セメント比 $41.7 \%$ 以 上）上なる。同様に単位セメント量との関係でみると, 外気温 $28^{\circ} \mathrm{C}$ 以下で構造体内温度が最高到達温度で $70^{\circ} \mathrm{C}$ 以下，または温度上昇量で $40^{\circ} \mathrm{C}$ 以下の条件を満 足するのは，柱断面寸法 $900 \times 900 \mathrm{~mm}$ の場合で単位. メント量 $480 \mathrm{~kg}$ 以下, 柱断面寸法 $1100 \times 1100 \mathrm{~mm}$ の 場合では単位セメント量 $430 \mathrm{~kg}$ 以下である。

1.3 セメント水比と設計基準強度の一般的な関係

一般に調合計画は材令 28 日標準養生供試体強度で行 うことが多い。そこでこの材令 28 日標準養生供試体強 度を標準強度と呼ぶことにする。セメント水比と標準強 度の関係は, 骨材の品質や混練方式などコンクリートを 製造するときの条件によって変わる。その関係は, 正式 にはコンクリートを製造する工場と骨材が決まり，空気 量などの調合計画条件が示されてから決まるものであ る。しかし，実用的な範井での骨材の品質や空気量の変 動，または製造条件が標準強度とセメント水比の関係に 与える影響に比べ, 標準強度はセメント水比とより密接 な関係をもっているから, 標準強度とセメント水比のお およその一般的な関係は分かる。図一4は昭和 61 年か ら平成 4 年までに大成建設技術研究所内で行った室内実 験の結果と,その間に行われた実際の工事を対象として, その工事にコンクリートを供給することが決まったコン クリート製造工場での小型ミキサーによる室内試し練り の試駼結果をグラフにしたものである。デー夕は大成建 設技術研究所内で行ったものが最も多く58\%を占め, 次いで東京都内の $19 \%$, 香川県での $8 \%$ となっている。 埼玉県, 神奈川県でのデー夕を含好と $83 \%$ が東京周 辺でのデータである。強度発現に比較的大きい影響をも つと考えられる空気量は， $1.0 \%$ から $6.0 \%$ まであり, 2 $5 \%$ の間が多い。平均値は $3.21 \%$ である。強度は

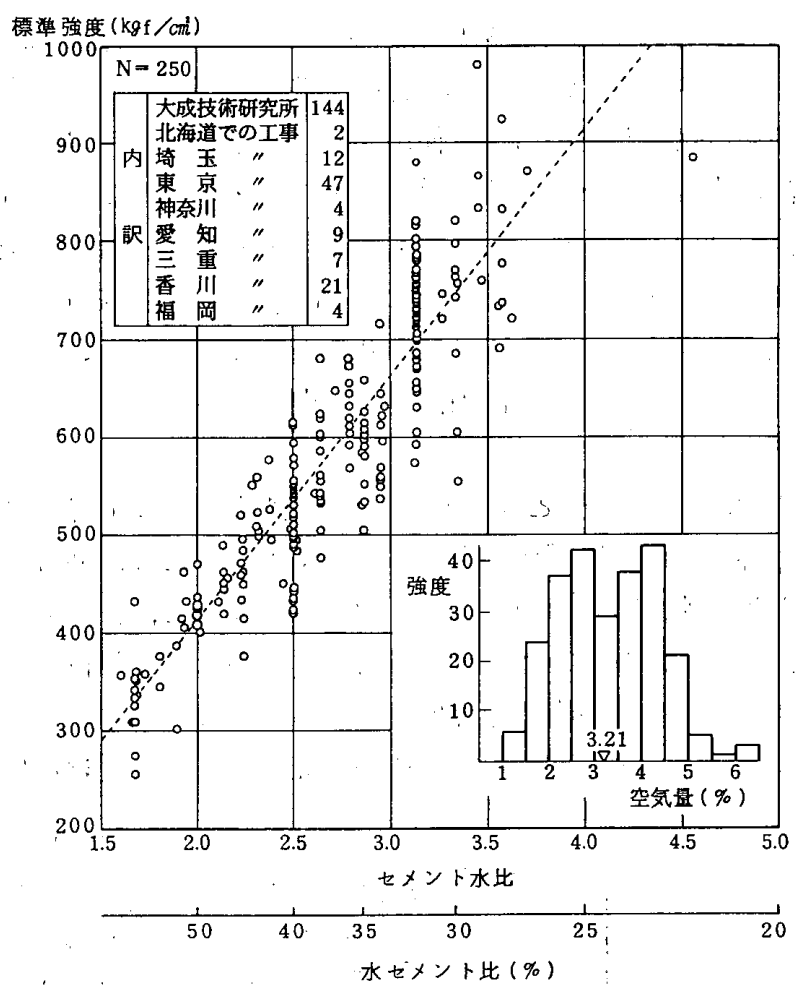

図一4セメント水比と標準強度の関係実績

標準強度 $\left(\mathrm{kgf}^{\prime} / \mathrm{cm}^{\mathrm{i}}\right)$

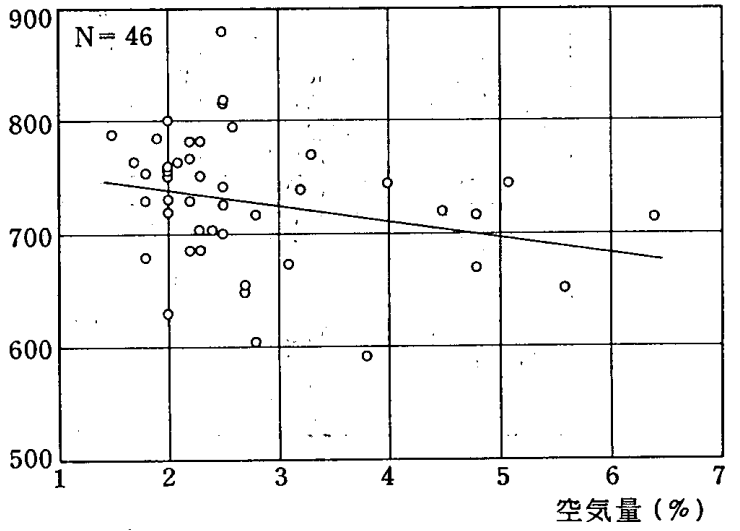

図一5 空気量と標準強度 (セメシト水比 3.13 )

$400 \sim 800 \mathrm{kgf} / \mathrm{cm}^{2}$ が多く平均値は $580 \mathrm{kgf} / \mathrm{cm}^{2}$, セメン 卜水比では $2.0 \sim 3.5$ が多く平均值は 2.66 , 水セメント 比では 30 45\%, 平均值は $39 \%$ である。また, 単位 水量では $165 \sim 180 \mathrm{~kg} / \mathrm{cm}^{3}$ が多くを占め平均值は 172 $\mathrm{kg} / \mathrm{m}^{3}$ である。グラフ中の直線は回帰式を示している。

標準強度と空気量の関係については, 図一4のなかで 最もデー夕数の多いセメント水比 3.13 (水セメント比 $32 \%$ ）の場合についてグラフにすると，図一5 のように なる。空気量 $1 \%$ に付き標準強度は約 $15 \mathrm{kgf} / \mathrm{cm}^{2}$ の減 少となる。15/730-0.02つまり空気量 1\%について約 $2 \%$ の強度減少である。したがって, 図一4は，空気量 補正を行うと多少は変わるが，おおよその傾向をみる上 においては有用であると考える。

図一 3 および図一 4 から，外気温 $28^{\circ} \mathrm{C}$ 以下つまり日 本国内であればほぼいずれの地方いずれの季節であって 
表一3 設計基淮强度とセメント水比

\begin{tabular}{|c|c|c|c|c|c|}
\hline \multicolumn{2}{|c|}{ 設計基準强度（kgf/c®） } & 420 & 480 & 540 & 600 \\
\hline 調合强度 & $(\mathrm{kgf} / \mathrm{cd})$ & 488 & 558 & 628 & 698 \\
\hline \multicolumn{2}{|c|}{ セメント水比 } & 2.31 & 2.59 & 2.87 & 3.16 \\
\hline \multicolumn{2}{|c|}{ 水セメント比 (\%) } & 43.3 & 38.6 & 34.8 & 31.6 \\
\hline \multicolumn{2}{|c|}{$\begin{array}{c}\text { 単位水量 } 165 \ell の と \\
\text { きの単位せメント吾 } \\
(\mathrm{kg})\end{array}$} & 381 & 422 & 474 & 521 \\
\hline
\end{tabular}

も，構造体内部の初期の上昇温度が最高到達温度て $70^{\circ} \mathrm{C}$ 以下または温度上昇量で $40^{\circ} \mathrm{C}$ 以下の条件を満足 する設計基準強度の大きさについて考える。今仮りに変 動係数を $7 \%$, 不良率 $2.3 \%$ 以下の条件で標準強度で の調合強度を計算すると，表一 3 の 1 行目のような設計 基準強度に対して，それぞれの調合強度は表一-3の 2 行 目の欄に示すようになる。さらに図一 3 の回州式を使っ てセメント水比，水セメント比を計算すると表一 3 の 3 行目，4行目に示す值になる。このセメント水比の值か ら単位水量がそれぞれ $175,155 \mathrm{~kg}$ の場合について単位 セメント量を計算し, 構造体内の温度上昇が最高到達温 度で $70^{\circ} \mathrm{C}$ 以下または温度上昇量で $40^{\circ} \mathrm{C}$ 以下の条件を 満足する設計基準強度を求めると，柱断面寸法 $900 \times$ $900 \mathrm{~mm}$ の場合で設計基準強度 $480 \mathrm{kgf} / \mathrm{cm}^{2}$ (単位水量 $175 \mathrm{~kg}$ ）または $540 \mathrm{kgf} / \mathrm{cm}^{2}$ （単位水量 $155 \mathrm{~kg}$ ）以下に なり，柱断面寸法 $100 \times 1100 \mathrm{~mm}$ の場合では, 設計基 準強度 $420 \mathrm{kgf} / \mathrm{cm}^{2}$ (単位水量 $175 \mathrm{~kg}$ ), $480 \mathrm{kgf} / \mathrm{cm}^{2}$ (単 位水量 $155 \mathrm{~kg}$ ）以下となる。高強度コンクリートの場合, 単位水量は実際 $165 l$ 程度の頻度が最も高いとみられる ので，その場合の単位セメント量を計算すると表一3の
5 行目に示す値になる。その值と図一 3 と併せて考える と，柱断面寸法 $900 \times 900 \mathrm{~mm}$ では，設計基準強度 540 $\mathrm{kgf} / \mathrm{cm}^{2}$ 以下，柱断面寸法 $1100 \times 1100 \mathrm{~mm}$ では設計基 準強度 $480 \mathrm{kgf} / \mathrm{cm}^{2}$ 以下である。したがって，高層の鉄 筋コンクリート造による集合住宅を想定し，柱断面寸法 は $1000 \times 1000 \mathrm{~mm}$ 程度の頻度が高いとすれば，単位七 メント量は $460 \mathrm{~kg}$ 以下程度になるから，ごく平均的に は設計基準強度 $540 \mathrm{kgf} / \mathrm{cm}^{2}$ 以下，安全を考えれば同 $480 \mathrm{kgf} / \mathrm{cm}^{2}$ 以下となる。つまり，設計基準強度 480 $\mathrm{kgf} / \mathrm{m}^{2}$ 以下であれば，構造体の硬化初期の急激な温度 上昇を考慮せずに調合計画が可能という言い方がおおよ そできるであろう。

\section{2. 硬化初期の温度上昇と強度発現}

\section{1 積算温度と各種養生供試体強度発現の関係}

筆者は高強度コンクリートについての調合計画は，積 算温度と構造体強度発現の関係をべースに考えるのが適 当であると考えている。設計基準強度と調合強度の関係 を考える前に，まず積算温度と各種供試体強度発現の関 係について検討する。

初期の構造体内温度上昇の大きさと，そのときの構造 体強度 (コア供試体強度), 標準強度及び現場封诚養生 供試体強度間の関係に関する実験については，本誌 445 号及び 449 号に報告した。この実験は，いろいろな温度 履歴条件下でのコア供試体強度を調査することを目的と して，施工場所，施工時期を種々に変えて行われたもの である。強度レベルとしては設計基準強度 $360 \mathrm{kgf} / \mathrm{cm}^{2}$ 程度から，通常の材料，製造条件下で得られる最高クラ

表一4 各実験における各種養生供試体強度と積算温度（普通ポルトランドセメント）

\begin{tabular}{|c|c|c|c|c|c|c|c|c|c|c|c|c|c|c|c|c|c|c|}
\hline \multirow{3}{*}{$\begin{array}{l}\text { 実験 } \\
\text { 番号 }\end{array}$} & \multicolumn{2}{|l|}{ 武 験 体 } & \multirow{3}{*}{$\begin{array}{c}\text { コンクリート } \\
\text { 打設時期 } \\
\text { (昭和又は } \\
\text { 平成年月) } \\
\end{array}$} & \multirow{3}{*}{$\begin{array}{c}\text { 試験体施工 } \\
\text { 堨 所 } \\
\text { (都道県) }\end{array}$} & \multirow{3}{*}{$\begin{array}{c}\text { コンクリート } \\
\text { の水セメント } \\
\text { 比 } \\
(\%) \\
\end{array}$} & \multirow{3}{*}{$\begin{array}{c}\text { 最高到達 } \\
\text { 温 } \begin{array}{l}\text { 度 } \\
\left({ }^{\circ} \mathrm{C}\right)\end{array}\end{array}$} & \multirow{3}{*}{$\begin{array}{c}\text { 温 } \\
\text { 上軠量 } \\
\left({ }^{\circ} \mathrm{C}\right)\end{array}$} & \multicolumn{7}{|c|}{ 供式体強度（kgf/cđ） } & \multicolumn{4}{|c|}{ 䅡算温度( $\left({ }^{\circ} \mathrm{D} \cdot \mathrm{D}\right)$} \\
\hline & \multirow{2}{*}{ 寸法（mm） } & \multirow{2}{*}{ 数 } & & & & & & \multicolumn{3}{|c|}{ 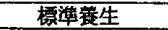 } & \multicolumn{2}{|c|}{ 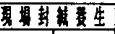 } & \multicolumn{2}{|c|}{ 構造体 (97) } & \multicolumn{2}{|c|}{ 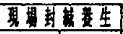 } & \multicolumn{2}{|c|}{ 構造体 (27) } \\
\hline & & & & & & & & 7 日 & 28日 & 91日 & 28日 & 91日 & 28 日 & 918 & 28日 & 91日 & 28 日 & 91 日 \\
\hline \multirow{2}{*}{$I^{2}$} & $850 \times 900 \times 2800$ (柱) & 1 & 60年10月 & \multirow{2}{*}{ 埼 玉 } & 39.0 & 59 & 36 & 432 & 519 & 578 & 516 & 569 & $\begin{array}{l}520 \\
502 \\
\end{array}$ & $\begin{array}{l}577 \\
552 \\
\end{array}$ & 610 & 1477 & 718 & 1585 \\
\hline & $850 \times 900 \times 2800$ (柱) & 1 & 60年11月 & & 40.0 & 67 & 43 & 342 & 420 & 501 & 444 & 505 & $\begin{array}{l}407 \\
426 \\
\end{array}$ & $\begin{array}{l}469 \\
547 \\
\end{array}$ & 553 & 1328 & 667 & 1442 \\
\hline II & $850 \times 850 \times 900$ & 5 & 63年 2 月 & 神奈川 & 33.0 & $\begin{array}{l}53 \\
53 \\
50 \\
49 \\
47 \\
\end{array}$ & $\begin{array}{l}38 \\
38 \\
35 \\
34 \\
32 \\
\end{array}$ & 467 & 587 & 685 & 505 & 647 & \begin{tabular}{|l|}
564 \\
529 \\
492 \\
519 \\
494 \\
\end{tabular} & $\begin{array}{l}618 \\
653 \\
617 \\
573 \\
563 \\
\end{array}$ & 411 & 1746 & $\begin{array}{l}566 \\
575 \\
562 \\
547 \\
557 \\
\end{array}$ & $\begin{array}{l}1901 \\
1910 \\
1897 \\
1882 \\
1892 \\
\end{array}$ \\
\hline \multirow{3}{*}{ III } & $850 \times 850 \times 1000$ & 1 & \multirow{3}{*}{$\frac{1 \text { 年8月 }}{1 \text { 年11月 }}$} & \multirow{3}{*}{ 北海道 } & 35.0 & 76 & 48 & 495 & 583 & 647 & 601 & 613 & 593 & 612 & 723 & 2304 & 722 & 2304 \\
\hline & $850 \times 850 \times 1000$ & 1 & & & 45.0 & 64 & 37 & 359 & 456 & 512 & 465 & 487 & 473 & 477 & & & 805 & 2386 \\
\hline & $850 \times 950 \times 2150$ & 1 & & & 36.6 & 45 & 22 & 484 & 550 & 610 & 447 & 539 & 476 & 547 & 483 & 847 & 554 & 968 \\
\hline IV & $\begin{array}{r}400 \times 400 \times 650 \\
250 \times 350 \times 650 \\
\end{array}$ & $\begin{array}{l}2 \\
1 \\
\end{array}$ & 1年12月 & $\begin{array}{l}20^{\circ} \mathrm{C} 80 \% の \\
\text { 室内 }\end{array}$ & 29.1 & $\begin{array}{l}64 \\
46 \\
43 \\
\end{array}$ & $\begin{array}{l}38 \\
20 \\
17\end{array}$ & 725 & 833 & 985 & 861 & 892 & $\begin{array}{l}880 \\
897 \\
961\end{array}$ & $\begin{array}{l}920 \\
905 \\
955\end{array}$ & 840 & 2730 & $\begin{array}{l}963 \\
910 \\
904\end{array}$ & $\begin{array}{l}2853 \\
2800 \\
2794\end{array}$ \\
\hline \multirow{3}{*}{ V } & $800 \times 800 \times 1800$ & 1 & 2年 8月 & \multirow{3}{*}{ 神寮川 } & \multirow{3}{*}{28.0} & 79 & 45 & 658 & 828 & 873 & 815 & 837 & 784 & 796 & 1064 & 3060 & 1152 & 3148 \\
\hline & $800 \times 800 \times 1800$ & 1 & 2年10月 & & & 70 & 44 & 654 & 804 & 856 & 820 & 853 & 747 & 809 & 791 & 2083 & 879 & 2171 \\
\hline & $800 \times 800 \times 1800$ & 1 & 2年12月 & & & 48 & 31 & 621 & 756 & 857 & 706 & 816 & 664 & 756 & 473 & 1539 & 543 & 1609 \\
\hline \multirow[t]{2}{*}{ VI } & $800 \times 800 \times 950$ & 2 & \multirow[t]{2}{*}{2 年8月 } & \multirow[t]{2}{*}{ 神奈川 } & 28.5 & $\begin{array}{l}87 \\
71 \\
\end{array}$ & $\begin{array}{l}50 \\
34\end{array}$ & 622 & 781 & 871 & 779 & 869 & $\begin{array}{l}775 \\
791\end{array}$ & $\begin{array}{l}772 \\
842\end{array}$ & 1010 & 2802 & $\begin{array}{l}1175 \\
1113\end{array}$ & $\begin{array}{l}2967 \\
2905\end{array}$ \\
\hline & $400 \times 600 \times 950$ & 1 & & & & 77 & 40 & & & & & & 759 & 782 & & & 1002 & $\frac{2894}{2894}$ \\
\hline & $1100 \times 1100 \times 3000$ & 1 & & & 27.0 & 96 & 58 & 715 & 836 & 902 & 806 & 894 & 703 & 740 & 1048 & 3108 & 1198 & 3238 \\
\hline VII & $1100 \times 1100 \times 3000$ & 2 & 3年7月 & 重 & 28.5 & $\begin{array}{l}95 \\
86\end{array}$ & $\begin{array}{l}56 \\
48\end{array}$ & $\begin{array}{l}663 \\
674\end{array}$ & $\begin{array}{l}753 \\
767\end{array}$ & $\begin{array}{l}853 \\
862\end{array}$ & 749 & 857 & $\begin{array}{l}672 \\
666\end{array}$ & $\begin{array}{l}707 \\
674\end{array}$ & & & $\begin{array}{l}1126 \\
1181\end{array}$ & $\begin{array}{l}3186 \\
3241\end{array}$ \\
\hline VII & $850 \times 850 \times 1000$ & 4 & 3年8月 & 京 & 28.0 & $\begin{array}{l}91 \\
88 \\
79 \\
82 \\
\end{array}$ & $\begin{array}{l}53 \\
50 \\
44 \\
47 \\
\end{array}$ & 534 & 665 & 757 & 651 & $\begin{array}{c}748 \\
\vdots \\
783 \\
\end{array}$ & $\begin{array}{l}590 \\
634 \\
692 \\
665 \\
\end{array}$ & $\begin{array}{l}634 \\
663 \\
754 \\
707 \\
\end{array}$ & 984 & 2949 & $\begin{array}{l}1110 \\
1105 \\
1089 \\
1076 \\
\end{array}$ & $\begin{array}{l}3075 \\
3070 \\
3054 \\
3041 \\
\end{array}$ \\
\hline & $850 \times 850 \times 1000$ & 1 & & & 26.0 & 87 & 49 & 582 & 707 & 765 & 684 & 780 & 671 & 719 & & & 1089 & 3054 \\
\hline & $850 \times 850 \times 900$ & 1 & 2年9月 & & 28.0 & 86 & 52 & 585 & 693 & 813 & 674 & 726 & 617 & 611 & 937 & 2553 & 1042 & 2658 \\
\hline
\end{tabular}




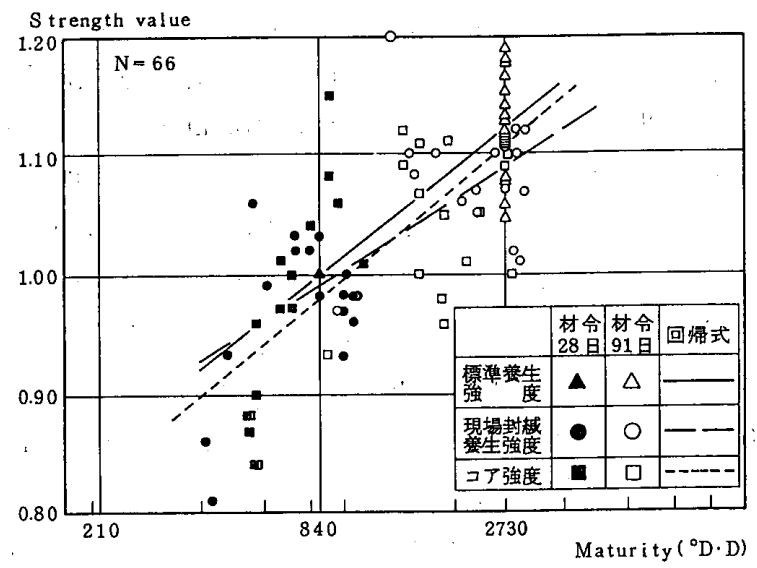

(a) 最高到達温度 $570^{\circ} \mathrm{C}$

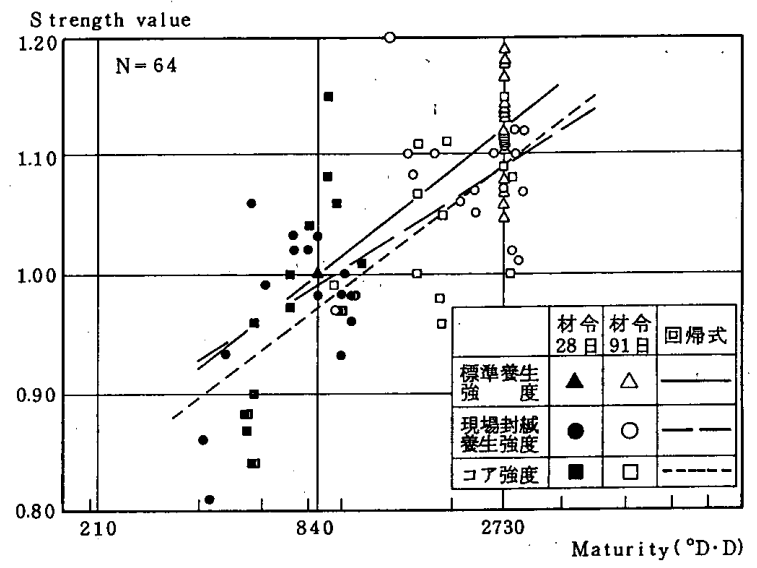

(b) 温度上年量 $\leqq 40^{\circ} \mathrm{C}$

図一6 標隻養生強度・現場封縅養生強度及びコア強度の個別強 度指数と積算温度

スの強度までを含んでいる。試験体の大きさは, 断面寸 法 $800 \times 1100 \mathrm{~mm}$ 角, 高さは $1000 \mathrm{~mm}, 2000 \mathrm{~mm}$ 前後, $3000 \mathrm{~mm}$ の 3 種である。その他の実験の詳細について は; 本誌 445 号及び 449 号と重複するので割愛し，その 強度試験結果についてのみ再度表一 4 に示す。

まず最初に，積算温度と各種養生供試体強度及びコア 供試体強度発現の関係からみていきたい。図一6は，表 -4 の材令 28,91日の結果について積算温度と各種養 生供試体強度，及びコア供試体強度の関係を図示したも のである。横軸には積算温度の常用対数目盛, 縦軸には 個別強度指数を用いている。個別強度指数とは，発現さ れた強度を標準強度との関係で評価するもので, 発現強 度/同一採取供試体の標準強度で計算される值である”。 コア供試体強度については，図一6(a) は最高到達温度 $70^{\circ} \mathrm{C}$ を超えるデー夕は除いており, 図一6(b) では温度 上昇量が $40^{\circ} \mathrm{C}$ を超えるデータは除いてある。供試体の 養生別に回帰直線を計算した結果もグラフに示してあ る。

図一6をみると, 各養生別に計算した回帰線は，(a), (b)ともにそれぞれほぼ同じ位置にあり，養生による 違いは見られない。回帰線から上下 1 割程度のばらつき

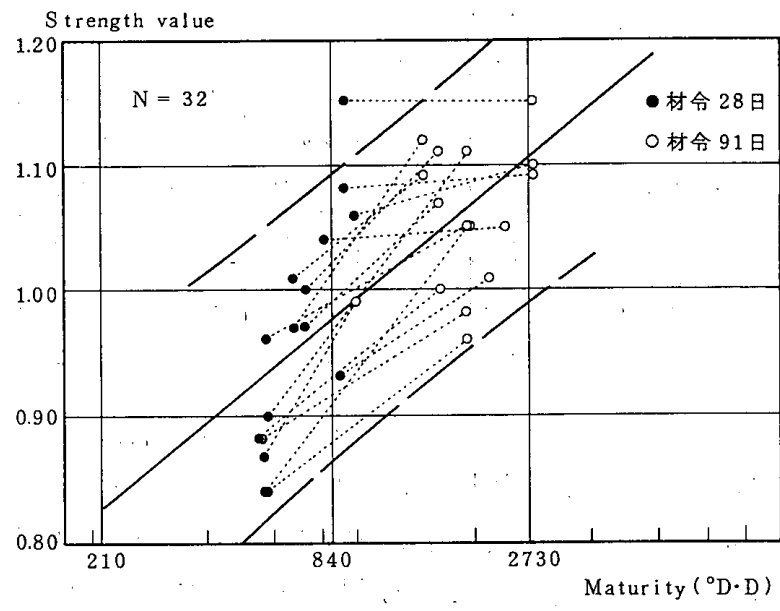

図一7コア強度の個別強度指数と積算温度（最高到達温度 $70^{\circ} \mathrm{C}$ )

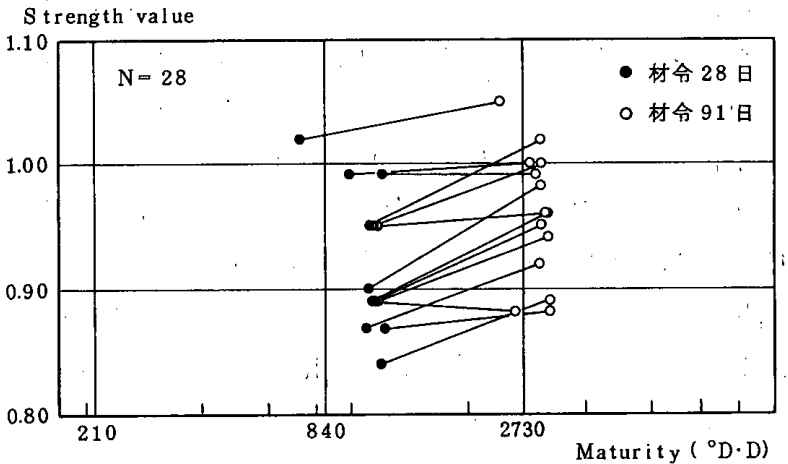

図一8コア強度の個別強度指数と積算温度（最高到達温度> $\left.70^{\circ} \mathrm{C}\right)$

を含んではいるが，養生の種類に関係なく積算温度に伴 う強度増進が見られる。したがって, 硬化初期における 構造体内の温度上昇が, 最高到達温度で $70^{\circ} \mathrm{C}$ 以下また は温度上昇量で $40^{\circ} \mathrm{C}$ 以下の場合は，標準養生供試体強 度, 現場封絾養生供試体強度及びコア供試体強度の強度 増進は，積算温度との関係において，それぞれが同程度 とみなせる。また，図一6(a)，(b) は同じような傾向を みせており，前述したようにおおよその傾向を見る上に おいては，最高到達温度 $70^{\circ} \mathrm{C}$ 以下の条件のみを取りあ げても差し支えないと考えられる。以降は最高到達温度 $70^{\circ} \mathrm{C}$ 以下の条件のみを使用する。

\section{2 積算温度とコア供武体強度発現の関係}

図一7は，表一4 から最高到達温度 $70^{\circ} \mathrm{C}$ 以下の条件 に合うものを選んで積算温度とコア供試体強度との関係 を表示したものである。中央の直線は回帰直線，上下の 破線は上下 $5 \%$ の萧却域を示している。材令 28 日と 91 日のデータをつないでいる点線は同一採取試料による データであることを示す。図一8は逆に，最高到達温度 が $70^{\circ} \mathrm{C}$ を超える場合についての積算温度とコア供試体 強度の関係を示したものである。図一 7 と図-8を比較 すると，図一7においては材令 28 日から材令 91 日への 強度の伸びが，概して大きくなっているのに対して，図 


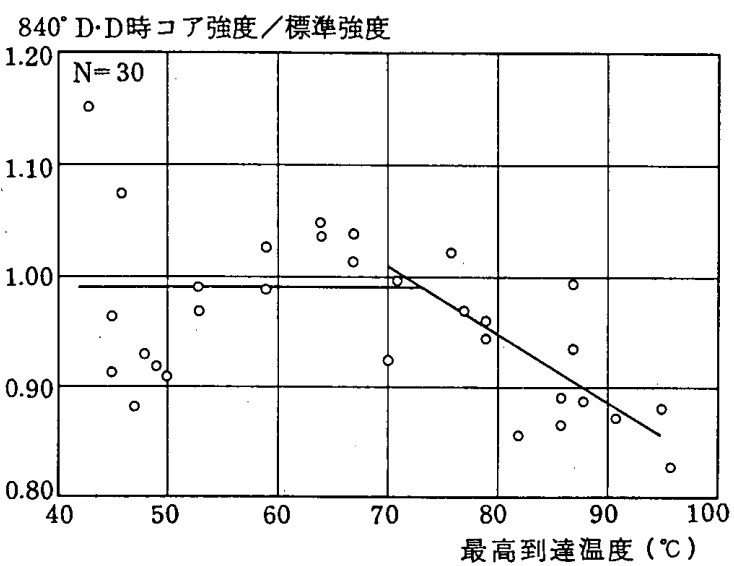

(a) $840^{\circ} \mathrm{D} \cdot \mathrm{D}$ 時

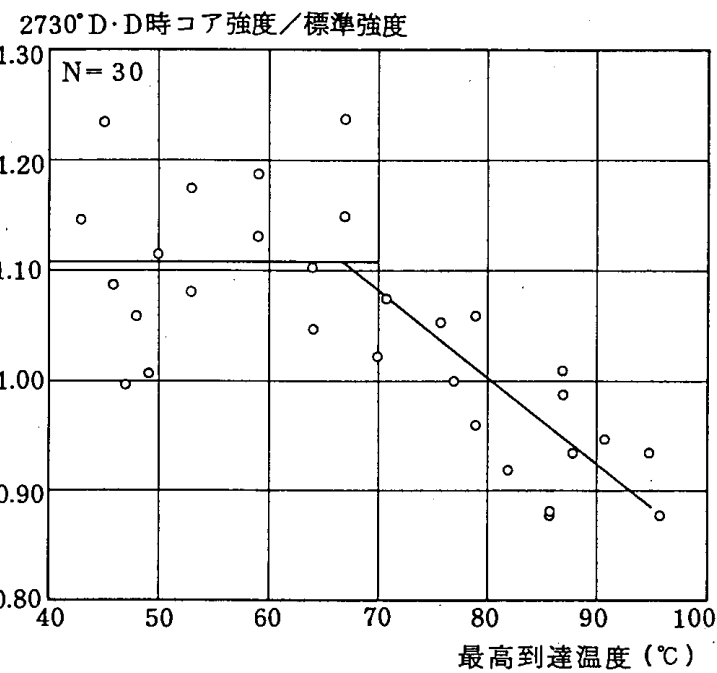

(b) $2730^{\circ} \mathrm{D} \cdot \mathrm{D}$ 時

図一9 最高到達温度とコア供試体個別強度指数

-8では，その值が逆に小さくなっている。図一7にお いて材令 28 日から材令 91 日へのコア供試体強度の伸び が小さいものは, 現場封縅養生供試体強度でも同様に小 さく, 前者が大きい場合は後者も大きい傾向がある。ま た, 図一 8 では 2 例を除き, 材令 28 日, 91 日の個別強 度指数の值は 1.00 以下, つまり材令 28 日, 91 日とも コア供試体強度は標準強度以下である。

$2.3840^{\circ} \mathrm{D} \cdot \mathrm{D}, 2730^{\circ} \mathrm{D} \cdot \mathrm{D}$ 時コア供試体強度と最高到 達温度

さらに, 標潐強度と比較した積算温度 $840^{\circ} \mathrm{D} \cdot \mathrm{D}$ 時及 び $2730^{\circ} \mathrm{D} \cdot \mathrm{D}$ 時コア供試体強度発現を, 最高到達温度 との関係で検討する。表一 4 の材令 28 日, 91 日の積算 温度はちょうど $840,2730^{\circ} \mathrm{D} \cdot \mathrm{D}$ とはなっていないので, $840^{\circ} \mathrm{D} \cdot \mathrm{D}$ 時及び $2730^{\circ} \mathrm{D} \cdot \mathrm{D}$ 時コア供試体強度に換算す る必要がある。その方法は, 強度・積算温度（常温対数 目盛）のグラフ上において，同一試料の材令 28 日と材 令 91 日のコア供試体強度を結んた線を延長し，その延 長した直線上における $840^{\circ} \mathrm{D} \cdot \mathrm{D}$ 及び $2730^{\circ} \mathrm{D} \cdot \mathrm{D}$ 時の読 み値を，それぞれのコア供試体強度とするものである。 材令 28 日と 91 日強度から比例配分によって求める。 図一9(a)，(b)は、このようにして求めた $840^{\circ} \mathrm{D} \cdot \mathrm{D}$ 時及び $2730^{\circ} \mathrm{D} \cdot \mathrm{D}$ 時コア供試体の個別強度指数を最高 到達温度との関係で図示したものである。図一 $9(\mathbf{a}) に$ おいて, 最高到達温度 $70^{\circ} \mathrm{C}$ 以下の横軸に平行な 0.99 の線は, 同 $70^{\circ} \mathrm{C}$ 以下の点の平均値である。同 $70^{\circ} \mathrm{C}$ を 超える部分について引いた斜めの線は, $70^{\circ} \mathrm{C}$ を超える データのみを対象としたときの最小 2 乗法による回帰線 である。この回帰線によると, $840^{\circ} \mathrm{D} \cdot \mathrm{D}$ 時コア供試体 強度は最高到達温度が $10^{\circ} \mathrm{C}$ 上るごとに個別強度指数は 0.06 の割合で小さくなる。また図一 9 (b) の横軸に平行 な 1.11 の線は, 図一 $9(\mathrm{a})$ 之同様に, 同 $70^{\circ} \mathrm{C}$ 以下の点 の平均値を示す線で, 同 $70^{\circ} \mathrm{C}$ を超える線分は同 $70^{\circ} \mathrm{C}$ を超えるデー夕を対象とする回帰線である。図一 9 (b) の場合はコア供試体強度発現への最高到達温度の影響は 同 $70^{\circ} \mathrm{C}$ 以前から始まり, 最高到達温度 $10^{\circ} \mathrm{C} こ ゙ と に$ 個 別強度指数が 0.08 減少しており, $840^{\circ} \mathrm{D} \cdot \mathrm{D}$ 時のときよ り強度減少の仕方が急激である。つまり, 最高到達温度 が $70^{\circ} \mathrm{C}$ を超えると $70^{\circ} \mathrm{C}$ から離れるにしたがって 2 $730^{\circ} \mathrm{D} \cdot \mathrm{D}$ コア供試体強度は, $840^{\circ} \mathrm{D} \cdot \mathrm{D}$ 時と同梯の比率 では期待できなくなり， $840^{\circ} \mathrm{D} \cdot \mathrm{D}$ 時から $2730^{\circ} \mathrm{D} \cdot \mathrm{D}$ 時 への強度増進が急激に小さくなる。

また, 図一9(a) では, 最高到達温度 $50^{\circ} \mathrm{C}$ 以下の部 分に強度比が 1.00 より小さいデータがいくぶん多い目 にあり，1.00より大きなデータとのバランスが多少徳 くなっている。今までの経験から考えて最高到達温度が 低い場合に,この強度比が 1.00 より小さくなる傾向が あるとは考えられない。事実これらの低い目の值も $2730^{\circ} \mathrm{D} \cdot \mathrm{D}$ 時での值は最高到達温度 $70^{\circ} \mathrm{C}$ 以下のデー夕 の平均値付近である。

\section{3. 高温履歴を受けない場合の設計基準強度の調合強度 の関係}

\section{1 設計基準強度と調合強度の一般的な関係}

高温履歴を受けない場合の設計基準強度と調合強度と の一般的な関係については, 設計基準強度 $360 \mathrm{kgf} / \mathrm{cm}^{2}$ を超える高強度コンクリートに, JASS 5 に記述されて いる高強度コンクリートの項と同様な構造体強度管理を 適用した場合を含め，すでに本誌 429 号に記述ずみであ り本誌 449 号でも触れた。ここでは本論文の理解に必要 な骨子のみを述べる。

JASS 5 には, 材令 28 日を超える中長期域で強度管 理を行う場合，設計基準強度と調合強度の関係を与える 式として，3つの条件式がある。それらは，(1)不良率が 決められた值以下になることを求める式，(2)ばらついて 製造される強度のうち，実質上ほほ最も小さいと考えら れる強度が, 設計基準強度の決められた割合の強度を実 質的に下回らないことを求める式，(3)材令 28 日におけ る構造体強度（この場合現場封緘養生供試体強度を意味 
する）が設計基準強度の $70 \%$ 以上であることを求める 式である。設計基準強度 $360 \mathrm{kgf} / \mathrm{cm}^{2}$ を超える高強度コ ンクリートの場合，不良率をJASS 5 に定義されている 高強度コンクリートの場合と同様に $2.3 \%$ 以下とする と, 製造されるコンクリートの強度が設計基準強度の値

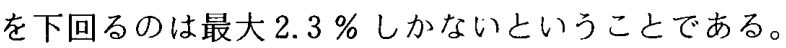
製造されたコンクリートの強度が実質的に設計基準強度 を下回るのは非常にまれである。したがって，(2)の条件 式は不要である。また, 設計基準強度 $360 \mathrm{kgf} / \mathrm{cm}^{2}$ を超 える高強度コンクリートでは早期強度の発現が大きいの で(3)の条件式は特に条件式としてとり上げる必要はな い。つまり，設計基準強度 $360 \mathrm{kgf} / \mathrm{cm}^{2}$ を超える高強度 コンクリートでは(1)の条件式だけでよい。

その他, 設計基準強度 $360 \mathrm{kgf} / \mathrm{cm}^{2}$ を超える高強度コ ンクリートの調合計画についての筆者の考え方は以下の 4 点にまとめられる。

(1) 積算温度と強度発現の関係をベースに考え, 各種養 生供試体強度及びコア供試体強度は積算温度をそろえて 評価する。

(2) 調合計画は常に標準強度で行う注。

(3) 調合強度を決める際に適用するばらつきの值は，標 淮強度分布のばらつきの值ではなく, 構造体強度を管理 する供試体の養生方法によって求めた供試体強度分布 の, 構造体強度を管理する積算温度時のばらつきの值を 使用する。

(4) コンクリートの強度評価は一元化した方がよい。と りあえずは標準強度によって評価する。すなわち, 現在 JASS 5 の品質管理で用いている使用するコンクリート の品質を判定する方法と同じにする。

本論文ではこの先, 標準養生供試体強度を構造体強度 管理に用いる場合の調合強度と設計基準強度の関係につ いて論じたい。そのため, 標準強度分布で構造体強度管 理を行う場合とコア供試体強度分布で構造体強度管理を 行う場合とを比較しながら話を進める。つまり，標準強 度分布で構造体強度管理を行う場合, 構造体強度を管理 する積算温度に心じてコア供試体強度分布の不良率がど のように変化するかを主題に話を進める。ただし，ここ でとり上げているコア供試体強度は，任意の部分から採 取した個々のコア供試体強度ではなく, 本誌 449 号に記 述したように，個々のコア供試体強度の平均值，すなわ ち，柱をモデルとした模擬部材から縦軸方向に採取して 求めた各個別コア供試体強度の平均值である。

構造体強度の発現時期を任意の積算温度が得られたと きとし，調合強度を標準強度で表すとすると，標準強度 分布で構造体強度管理を行う場合, 及びコア供試体強度 分布で構造体強度管理を行う場合の設計基準強度と調合 強度の関係は，それぞれ次のような式で表せる。

$$
F_{1}=F_{c}+2 \cdot{ }_{s} \sigma_{\mathbf{8 4 0}}
$$

$$
F_{2}=\left(F_{c}+2 \cdot{ }_{c} \sigma_{m}\right) /{ }_{c} r_{m}
$$

$F_{1}$ : 標準強度分布で構造体強度を管理する場合の標 準強度での調合強度

$F_{2}$ : 積算温度 $m{ }^{\circ} \mathrm{D} \cdot \mathrm{D}$ 時のコア供試体強度分布で構 造体強度を管理する場合の標準強度での調合強 度

$F_{c}$ : 設計基準強度

${ }_{s} \sigma_{840}$ : 積算温度 $840^{\circ} \mathrm{D} \cdot \mathrm{D}$ 時標準養生供試体強度（す なわち標準強度）分布の標準偏差

${ }_{c} \sigma_{m}$ : 積算温度 $m^{\circ} \mathrm{D} \cdot \mathrm{D}$ 時コア供試体強度分布の標準 偏差

${ }_{c} r_{m}$ : 同一調合のコンクリート群において, 積算温度 $m^{\circ} \mathrm{D} \cdot \mathrm{D}$ 時コア供試体強度分布の平均值を, 標 準強度分布の平均值で徐した值

（1）式は，構造体強度の管理をあらかじめ設定した 積算温度時の現場封絾養生供試体強度分布やコア供試体 強度分布の值を使用して行うのではなく, 間接的に構造 体強度の管理を標準強度分布で行うときの, 設計基準強 度と調合強度との関係を示す式である。これに対して (2) 式は，あらかじめ設定した積算温度時のコア供試 体強度分布で直接構造体強度管理を行う場合の条件式で ある。すなわち構造体強度発現を期待する積算温度 $m^{\circ}$ $\mathrm{D} \cdot \mathrm{D}$ 時のコア供試体強度分布において, 不良率が 2.3 \% 以下の条件を満たすこ之を条件とする場合の条件式 である（コア供試体強度分布で構造体強度を管理するの ではなく, 現行 JASS 5 の高強度コンクリートの項に準 じて, 現場封絾養生供試体強度分布で構造体強度管理を 行う場合は, (2) 式のコア供試体強度分布の代わりに 現場封縅養生供試体強度分布の值を使用することにな る)。

注）これと区別するため, 本論文では, 標準強度分布を想 定して不良率を定め, 標準強度で構造体強度を管理す るいわゆるポテンシャル管理をする場合を，標準強度 分布で構造体強度を管理するといういい方をする。同 様に，所定の材令または積算温度時の現場封絾養生供 試体強度分布を想定して不良率を定め，その現場封縅 養生供試体強度で構造体強度を管理することを所定の 材令はまたは積算温度時現場封緘養生供試体強度分布 で構造体強度を管理すると言う。

3.2 標準強度分布に上る構造体強度管理とコア供試体 強度分布における不良率

ここでは，構造体強度管理に標準強度分布を適用した ときの, 標準強度分布における不良率とコア供試体強度 分布における不良率の関係について検討する。

\section{2 .1 任意の積算温度時コア供試体強度分布の計算}

（2）式の条件式で調合計画を行う場合, 任意の積算 温度 $m^{\circ} \mathrm{D} \cdot \mathrm{D}$ 時におけるコア供試体強度分布での標準偏 差の值が必要である。

筆者は本誌 428 号と 449 号とに 2 つ強度分布に関す 
る実験式を示した。これは， $A, B 2 つ$ 強度分布があ るとき, $A$ 強度分布及び $B$ 強度と $A$ 強度の比の分布加 ら, $B$ 強度分布を予測する実験式である。次式で表せる。

$$
B(l)=\iint A(j) \cdot K \cdot R(i) d_{j} d_{i}
$$

$B(l): B$ 強度分布の確率密度関数

$A(j): A$ 強度分布の確率密度関数

$R(i): B$ 強度 $/ A$ 強度（比）の確率密度関係

$K:$ 補正係数

$K$ は $A$ 強度分布, $B$ 強度分布の関係から決定される 実験定数で, $K=1.0$ の場合は $B$ 強度分布の可能性の範 囲を示し(モデル I)， $K<1.0$ の場合は可能性の最も 高い $B$ 強度分布の予測をするもの（モデル II）である。 本論文ではモデル I を使用する。

いま, $A$ 強度分布を標準強度分布, $B$ 強度分布を $840^{\circ} \mathrm{D} \cdot \mathrm{D}$ 時コア供試体強度分布とする。 $840^{\circ} \mathrm{D} \cdot \mathrm{D}$ 時コ ア供試体強度・標準強度比の分布については，表一4の 結果から本誌 449 号に計算法を示した方法で得られたコ ア・標準養生強度比分布を使用する。これは，表一4の 材令 28 .日，91 日コア供試体と同じ積算温度時の標準養 生供試体強度を材令 28 日と 91 日標準養生供試体強度か ら比例配分によって計算し，その值で材令 28 日，91 日 コア供試体強度を徐した比の分布である。この分布の平 均値は 0.97 ，標準偏差は 0.063 である。

同様にして $A$ 強度分布を材令 91 日標準養生供試体強 度分布, $2730^{\circ} \mathrm{D} \cdot \mathrm{D}$ 時コア供試体強度・材令 91 日標準
養生供試体強度比分布を，上記のコア・標準養生強度比 分布とすれば， B 強度分布すなわち $2730^{\circ} \mathrm{D} \cdot \mathrm{D}$ 時コア 供試体強度分布が計算できる。 $840 \sim 2730^{\circ} \mathrm{D} \cdot \mathrm{D}$ 時間の コア供試体強度分布は, $840^{\circ} \mathrm{D} \cdot \mathrm{D}$ 時及び $2730^{\circ} \mathrm{D} \cdot \mathrm{D}$ 時 コア供試体強度分布から比例配分によって計算する。

群強度指数 ${ }^{1)}$ で表したとき（群強度指数とは，各材令 または積算温度時点での各種供試体強度を，標準強度で の調合強度を 1.0 とした指数で表現するものである。)， 標準強度分布は平均值 1.0 , 標準偏差 0.07 , 材令 91 日 標準養生供試体強度分布は平均值 1.12, 標準偏差 0.09 とすると, ( 3 )式モデル Iで計算したコア供試体強度(群 強度指数）分布の平均值之標準偏差の值は $840^{\circ} \mathrm{D} \cdot \mathrm{D}$ 時 でそれぞれ $0.97,0.09,2730^{\circ} \mathrm{D} \cdot \mathrm{D}$ 時で $1.08,0.11$ と なる。これらの平均值を図一 $9(\mathrm{a})$ ，（b）の最高到達温度 $70^{\circ} \mathrm{C}$ 以下の部分の平均值と比べるといくぶん低い值と なっている。これは, 群強度指数では標準強度自身が標 準強度分布平均值より低いことが起こり得るからであ る。図一9(a)，(b) の縦軸は個別強度指数を表しており， 群強度指数で表される平均值が $840^{\circ} \mathrm{D} \cdot \mathrm{D}$ 時, $2730^{\circ}$ $\mathrm{D} \cdot \mathrm{D}$ 時いずれにおいても最高到達温度 $70^{\circ} \mathrm{C}$ 以下の平均 値を表す実線よりやや低い值になっているのは理解でき る。

$840^{\circ} \mathrm{D} \cdot \mathrm{D}$ 時及び $2730^{\circ} \mathrm{D} \cdot \mathrm{D}$ 時コア供試体強度（群強 度指数）分布の計算された值を用いて, $840^{\circ} \mathrm{D} \cdot \mathrm{D}$ から $2730^{\circ} \mathrm{D} \cdot \mathrm{D}$ 時までの標準養生供試体強度（群強度指数） 分布及びコア供試体強度（群強度指数）分布における平
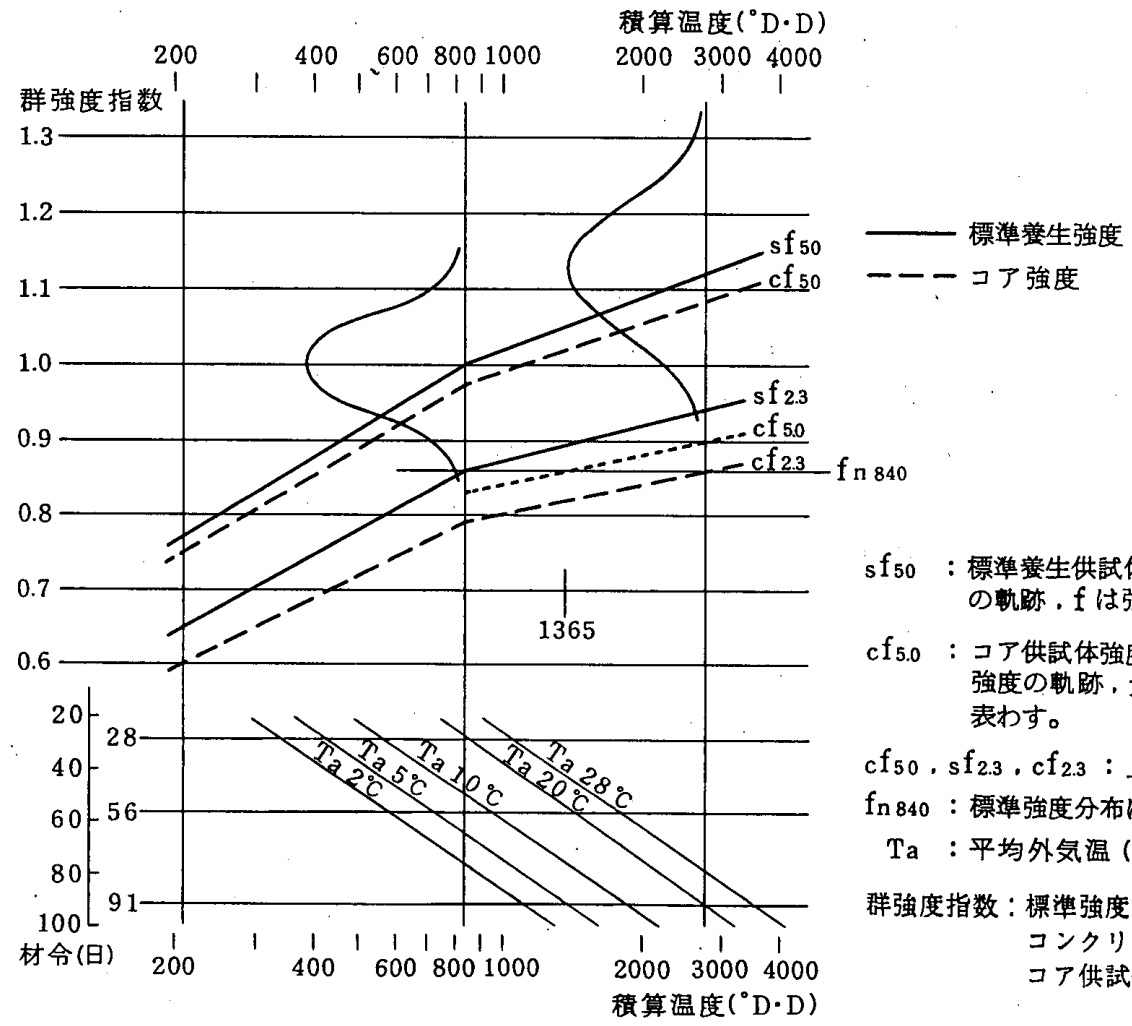

図一10 積算温度と標準養生及びコア強度分布（強度は群強度指数表示) 
均值と不良率 $2.3 \%$ の位置を示す強度 (群強度指数) の軌跡をかけば図一10となる。図一10（強度はすべて 群強度指数）において, 不良率 $50 \%$ つまり平均值を表 す標準養生供試体強度の軌跡は $s f_{50}$ で示す実線であり, 同不良率 $2.3 \%$ の位置の軌跡は $s f_{2.3}$ の実線である。同 様に点線はコア供試体強度分布の場合を表す。図一10 によれば，コア供試体強度分布における不良率 $2.3 \%$ の位置を示す強度の值は, 積算温度に応じて高くなって いる。図一10 の下の部分のグラフは材令と積算温度の 関係を示すものである。例えば材令 28 日の場合は平均 外気温が $2^{\circ} \mathrm{C}$ であれば積算温度は $336^{\circ} \mathrm{D} \cdot \mathrm{D}, 28^{\circ} \mathrm{C}$ であ れば $1064^{\circ} \mathrm{D} \cdot \mathrm{D}$ であり, 平均外気温に応じて材令 28 日 の場合は $336 \sim 1064^{\circ} \mathrm{D} \cdot \mathrm{D}$ 間の積算温度をとることを示 している。

\section{2 .2 積算温度の経過とコア供試体強度分布不良率の 変化}

図一10（強度はすべて群強度指数）にみるように, 標 準強度分布で所要強度を下まわる不良率 $2.3 \%$ 以下の 条件で製造されたコンクリート群は，材令の経過によっ て積算温度が増加するとともに所要強度を超える強度の 存在割合が高くなり，コア供試体強度の不良率は小さく なる。構造体が, $2730^{\circ} \mathrm{D} \cdot \mathrm{D}$ の積算温度が得られる材令 になれば, コア供試体強度分布で所要強度を下回る不良 率は，標準強度分布で設定した不良率 $2.3 \%$ 以下と同 じ不良率になる。このことは, 図一10において，標準 強度で不良率 $2.3 \%$ 以下で注文したときの注文強度 $f_{n 840}$ (不良率 $4.17 \%$ 以下を不良率 $2.3 \%$ 以下に読みか えた呼び強度を意味する。）を表す横軸に平行な直線と， コア供試体強度分布で評価したとき不良率 $2.3 \%$ を表 す位置 $c f_{2.3}$ の軌跡の線が, 積算温度 $2730^{\circ} \mathrm{D} \cdot \mathrm{D}$ の位置 で交わっていることに示されている。このコンクリート は構造体が $840^{\circ} \mathrm{D} \cdot \mathrm{D}$ の積算温度が得られた時点では, 構造体強度分布 (コア供試体強度分布) 評価では所要強 度を下回る不良率は $2.3 \%$ より大である。そのときの 不良率は次のように計算される。群強度指数で表したと き，表一4，（3）式，モデル Iによって計算した $840^{\circ}$ $\mathrm{D} \cdot \mathrm{D}$ 時コア供試体強度分布での平均値 $c r_{840}$ と標準偏差 ${ }_{c} \sigma_{840}$ の値は, それぞれ $0.97,0.09$ である。標準強度分 布での標準偏差は 0.07 であるから，所要強度は $1-2 \times$ $0.07=0.86$ ，つまり $f_{n 840}=0.86$ である。したがって， $(0.97-0.86) / 0.09=1.22$ より, 不良率は $11.1 \%$ であ る。

筆者は本誌 419 号に, 構造体強度を現場封縅養生供試 体強度で管理する場合についての検討を行い, $1365^{\circ}$ $\mathrm{D} \cdot \mathrm{D}$ の積算温度が得られれば気温補正は不要である。 つまり, 設計基準強度で考えたとき $1365^{\circ} \mathrm{D} \cdot \mathrm{D}$ 時現場 封絾養生供試体強度分布においては標準強度分布での不 良率と同じ不良率が得られることを述べた。この場合す
なわち $1365^{\circ} \mathrm{D} \cdot \mathrm{D}$ 時のコア供試体強度分布での不良率 は，図一10 (強度は群強度指数表示) に示すように積算 温度 $1365^{\circ} \mathrm{D} \cdot \mathrm{D}$ 時のコア供試体強度分布が ${ }_{c} f_{5.0}$ の線と 交わるから, 所要強度（すなわち設計基準強度）を下回 る不良率の值は $5.0 \%$ であ。つまり, 図一10のよう な関係が成立する条件下においては，構造体強度管理を 不良率 $2.3 \%$ 以下を条件とする標準強度分布で行うこ とは，不良率 $2.3 \%$ 以下を条件とする $1365^{\circ} \mathrm{D} \cdot \mathrm{D}$ 時現 場封縅養生供試体強度分布, 不良率 $5.0 \%$ 以下を条件 とする $1365^{\circ} \mathrm{D} \cdot \mathrm{D}$ 時コア供試体強度分布で行うことに 等しく,さらに，前述したように不良率 $2.3 \%$ 以下を 条件亡する $2730^{\circ} \mathrm{D} \cdot \mathrm{D}$ 時コア供試体強度分布で行うの にも等しい。

逆に,コア供試体強度分布で設計基準強度を下回る不 良率 $5.0 \%$ 以下を是認すれば, $2730^{\circ} \mathrm{D} \cdot \mathrm{D} コ ア$ 供試体 強度分布で, 不良率 $5.0 \%$ 以下の条件で, 構造体強度 を管理する場合の設計基準強度は, 群強度指数で表すと 図一10より0.90であるから, 標準強度での調合強度は, 標準強度分布で設計基準強度を下回る不良率 $2.3 \%$ 以 下 $\left(=1365^{\circ} \mathrm{D} \cdot \mathrm{D}\right.$ 時現場封縅養生供試体強度分布で不良 率 $2.3 \%$ 以下）の条件で製造したコンクリート群に比 べて, $(1 / 0.90) /(1 / 0.86)=0.96$ つまり $4 \%$ 調合強度 を低く設定できる。

さらに，図一 10 において $2730^{\circ} \mathrm{D} \cdot \mathrm{D}$ 時標準養生供試 体強度分布で設計基準強度を下回る不良率が $2.3 \%$ 以 下となる条件で調合計画を行う場合を考える。そのとき の設計基準強度は $(1.12-20 \times 0.09)$ より 0.94 である。 この場合の標準強度での調合強度は, $840^{\circ} \mathrm{D} \cdot \mathrm{D}$ 時標準 養生供試体強度分布（=標準強度分布）で設計基準強度 を下回る不良率 $2.3 \%$ 以下の条件で行う調合強度に比 べて $(1 / 0.94) /(1 / 0.86)=0.91 つ ま り 9 \%$ 小さく設定 できる。 $840^{\circ} \mathrm{D} \cdot \mathrm{D}$ 時コア供試体強度分布評価では不良 率は $(0.97 \sim 0.94) / 0.09=0.33$ より $37 \%, 2730^{\circ} \mathrm{D} \cdot \mathrm{D}$ 時コア供試体強度分布評価では $(1.08-0.94) / 0.11=$ 1.27 より $10.2 \%$ である。現在のレデミクストコンク リート製造における不良率が $4.17 \%$ 以下であるから， 不良率 $10.2 \%$ でば不良率が大きいようにも思えるが， 最初に調合計画に統計の考え方が導入された昭和 32 年 版 JASS 5 での不良率が $16 \%$ だったことを思えば，不 良率 $10.2 \%$ というのは決して大きすぎる値ではない。 その JASS 5 には不良率 $16 \%$ は材料関係者と構造関係 者の協議によって決定したと解説されている。不良率を 理由もなく大きくすることは許されるべきことではない が，不良率 $16 \%$ も許容されていた時期が存在したこと は確かである。このようなことから，筆者は施工条件に よっては $2730^{\circ} \mathrm{D} \cdot \mathrm{D}$ 時標準養生供試体強度分布でのポ テンシャル評価位までは高強度コンクリートの調合計画 に適用してもよいのではないかと考える。 
表一5 それぞれの積算温度を達成するに要する日数

\begin{tabular}{|c|c|c|c|c|c|c|c|c|c|c|c|c|c|c|}
\hline 䯅 & 月 & & 1 & 2 & 3 & 4 & 5 & 6 & 7 & 8 & 9 & 10 & 11 & 12 \\
\hline & & 上旬 & 105 & 84 & 63 & 46 & 37 & 32 & 28 & 26 & 32 & 44 & 94 & 117 \\
\hline & $840^{\circ} \mathrm{D} \cdot \mathrm{D}$ & 中旬 & 98 & 77 & 57 & 43 & 35 & 31 & 26 & 27 & 35 & 53 & 111 & 115 \\
\hline & & 下旬 & 91 & 69 & 51 & 39 & 33 & 29 & 26 & 28 & 39 & 69 & 117 & 111 \\
\hline 札 & & 上旬 & 132 & 109 & 87 & 69 & 57 & 50 & 44 & 44 & 57 & 107 & 156 & 150 \\
\hline & $1365^{\circ} \mathrm{D} \cdot \mathrm{D}$ & 中旬 & 125 & 102 & 80 & 64 & 55 & 48 & 43 & 46 & 65 & 138 & 156 & 145 \\
\hline 榥 & & 下旬 & 117 & 94 & 74 & 60 & 52 & 46 & 43 & 50 & 80 & 151 & 154 & 139 \\
\hline & & 上旬 & 187 & 162 & 138 & 117 & 102 & 93 & 92 & 109 & 213 & 226 & 222 & 208 \\
\hline & $2730^{\circ} \mathrm{D} \cdot \mathrm{D}$ & 中旬 & 178 & 154 & 130 & 111 & 98 & 92 & 95 & 129 & 221 & 226 & 218 & 201 \\
\hline & & 下旬 & 170 & 146 & 123 & 106 & 96 & 91 & 100 & 174 & 225 & 225 & 213 & 194 \\
\hline & & 上旬 & 73 & 64 & 51 & 40 & 33 & 29 & 26 & 24 & 28 & 35 & 49 & 69 \\
\hline & $840^{\circ} \mathrm{D} \cdot \mathrm{D}$ & 中旬 & 70 & 59 & 47 & 37 & 32 & 28 & 25 & 25 & 30 & 39 & 57 & 72 \\
\hline & & 下旬 & 67 & 55 & 43 & 35 & 30 & 27 & 24 & 25 & 32 & 43 & 64 & 73 \\
\hline 仙 & & 上旬 & 104 & 89 & 74 & 60 & 52 & 46 & 41 & 40 & 49 & 65 & 96 & 111 \\
\hline & $1365^{\circ} \mathrm{D} \cdot \mathrm{D}$ & 中旬 & 99 & 84 & 69 & 57 & 50 & 45 & 40 & 42 & 53 & 74 & 105 & 110 \\
\hline 台 & & 下旬 & 95 & 79 & 64 & 54 & 48 & 43 & 40 & 44 & 58 & 85 & 109 & 108 \\
\hline & & 上旬 & 160 & 142 & 123 & 107 & 95 & 86 & 84 & 91 & 133 & 176 & 183 & 175 \\
\hline & $2730^{\circ} \mathrm{D} \cdot \mathrm{D}$ & 中旬 & 154 & 135 & 117 & 103 & 91 & 85 & 85 & 98 & 152 & 181 & 181 & 171 \\
\hline & & 下旬 & 148 & 129 & 112 & 98 & 89 & 84 & 87 & 109 & 167 & 182 & 178 & 166 \\
\hline & & 上旬 & 56 & 51 & 42 & 34 & 29 & 26 & 24 & 22 & 25 & 31 & 39 & 51 \\
\hline & $840^{\circ} \mathrm{D} \cdot \mathrm{D}$ & 中旬 & 55 & 48 & 39 & 32 & 28 & 26 & 23 & 23 & 27 & 33 & 43 & 54 \\
\hline & & 下旬 & 53 & 45 & 37 & 31 & 27 & 25 & 22 & 23 & 29 & 36 & 47 & 55 \\
\hline 果 & & 上旬 & 85 & 75 & 63 & 53 & 46 & 42 & 38 & 37 & 43 & 54 & 72 & 86 \\
\hline & $1365^{\circ} D \cdot D$ & 中旬 & 82 & 71 & 59 & 50 & 45 & 41 & 37 & 38 & 46 & 59 & 78 & 87 \\
\hline 京 & & 下旬 & 79 & 67 & 56 & 48 & 43 & 39 & 36 & 39 & 50 & 65 & 83 & 87 \\
\hline & & 上旬 & 139 & 124 & 109 & 96 & 87 & 79 & 76 & 81 & 105 & 139 & 154 & 151 \\
\hline & $2730^{\circ} \mathrm{D} \cdot \mathrm{D}$ & 中旬 & 135 & 119 & 104 & 93 & 84 & 78 & 76 & 86 & 116 & 146 & 154 & 148 \\
\hline & & 下旬 & 130 & 114 & 100 & 89 & 81 & 77 & 78 & 92 & 129 & 151 & 153 & 144 \\
\hline & & 上旬 & 32 & 31 & 29 & 27 & 25 & 23 & 22 & 22 & 22 & 24 & 26 & 29 \\
\hline & $840^{\circ} \mathrm{D} \cdot \mathrm{D}$ & 中旬 & 32 & 31 & 29 & 26 & 24 & 22 & 21 & 22 & 23 & 25 & 27 & 30 \\
\hline & & 下旬 & 32 & 30 & 28 & 25 & 24 & 22 & 22 & 22 & 23 & 25 & 29 & 31 \\
\hline 那 & & 上旬 & 52 & 50 & 47 & 43 & 40 & 37 & 35 & 36 & 37 & 40 & 45 & 50 \\
\hline & $1365^{\circ} \mathrm{D} \cdot \mathrm{D}$ & 中旬 & 52 & 49 & 45 & 41 & 39 & 36 & 35 & 36 & 38 & 41 & 46 & 51 \\
\hline 婻 & & 下旬 & 51 & 48 & 44 & 40 & 38 & 36 & 35 & 36 & 39 & 43 & 48 & 51 \\
\hline & & 上旬 & 100 & 95 & 88 & 82 & 76 & 73 & 71 & 73 & 78 & 87 & 96 & 101 \\
\hline & $2730^{\circ} \mathrm{D} \cdot \mathrm{D}$ & 中旬 & 99 & 92 & 86 & 80 & 75 & 72 & 72 & 74 & 81 & 90 & 98 & 101 \\
\hline & & 下旬 & 97 & 90. & 84 & 78 & 74. & 72 & 72 & 75 & 84 & 93 & 100 & 101 \\
\hline
\end{tabular}

受けるときと受けないときの

強度発現の差の割合

（4）式は標準強度分布で構造体強 度管理を行う場合であり，（5）式は 任意の積算温度 $m^{\circ} \mathrm{D} \cdot \mathrm{D}$ 時のコア供試 体強度分布で構造体強度管理を行う場 合である。

\section{5. 調合強度計算例}

図一11 は，ある工事における水七 メント比と強度の関係, 及び平均気温 ごとの設計基準強度と柱での最高到達 温度との関係を示すものである。標準 強度分布で構造体強度の管理を行う場 合でかつ高温履歴の影響を受けない場 合の水セメント比と設計基準強度との 関係は変動係数を $7 \%$ として計算す ると, 図-11 の下のグラフ横軸に示 すような関係になる。設計基準強度 $600 \mathrm{kgf} / \mathrm{cm}^{2}$ の場合について, 高温履 歴の影響を受ける場合と受けない場 合, 及び構造体強度管理を標準強度分

本誌 419 号に筆者は，積算温度的にみた場合日本国内 は札幌, 仙台, 新潟, 東京以西本州, 沖縄の四地域にお およそ分類できることを示した。積算温度 $840^{\circ} \mathrm{D} \cdot \mathrm{D}$, $1363^{\circ} \mathrm{D} \cdot \mathrm{D}, 2730^{\circ} \mathrm{D} \cdot \mathrm{D}$ が得られるそれら四地域での日 数を, 丸善発行の理科年表の気温の半旬別平均值を用い て計算すると表一5のようになる。東京でいえば $1365^{\circ}$. D.D は材令 91 日以内には達成できそうであり, $2730^{\circ}$ $\mathrm{D} \cdot \mathrm{D}$ を最高 154 日であるから約 5 か月で達成できる。

\section{4. 高温履歴を受ける場合の設計基準強度と調合強度の 関係}

初期の構造体温度上昇が大きい場合の設計基準強度と 調合強度の関係は次式のようになる。

$$
\begin{aligned}
& F_{4}=\left(F_{c}+2 \cdot{ }_{s} \sigma_{840}\right) /\left(1-h_{0}\right) \cdots \cdots . . \\
& F_{5}=\left\{\left(F_{c}+2 \cdot{ }_{s} \sigma_{m}\right) /\left(1-h_{m}\right)\right\} /{ }_{c} r_{m}
\end{aligned}
$$

$F_{4}$ : 標準強度分布で構造体強度を管理する場合の標 準強度での調合強度

$F_{5}$ : 積算温度 $m^{\circ} \mathrm{D} \cdot \mathrm{D}$ 時のコア供試体強度分布で構 造体強度を管理する場合の標準強度での調合強 度

$h_{0}$ ：標準強度分布で構造体強度を管理する場合に, 間接的に想定している任意の積算温度時コア供 試体が高温履歴によって受ける強度発現の低下 割合

$h_{m}$ : 構造体強度を管理する任意の積算温度 $m^{\circ} \mathrm{D} \cdot \mathrm{D}$ 時コア供試体強度において, 高温履歴の影響を
布, 不良率 $2.3 \%$ 以下と $2730^{\circ} \mathrm{D} \cdot \mathrm{D}$ 時標準養生供試体 強度分布, 不良率 $2.3 \%$ 以下で行う場合の, 調合強度 を計算する。

構造体強度管理を標準強度分布で行い, 高温履歴の影 響を受けない場合の調合強度は，変動係数を $7 \%$ とす ると図一11上のグラフにも示してあるように，600/(1 -2×0.07)-698 kgf/cm² である。図一11下のグラフか ら, $698 \mathrm{kgf} / \mathrm{cm}^{2}$ すなわち水セメント比 $31.5 \%$ の位置 では，平均気温が $23^{\circ} \mathrm{C}$ を超える位になると高温履歴の 影響を受けるようになる。この場合, 調合強度を上げる と平均気温 $28^{\circ} \mathrm{C}$ の場合では柱内最高到達温度は $80^{\circ} \mathrm{C}$

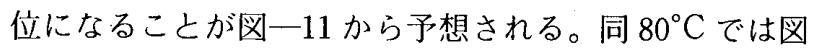
-9(a) より同 $70^{\circ} \mathrm{C}$ 以下の場合と比べるとコア供試体 強度の低下率は $0.04 / 0.99=0.04$ 位である。標準強度分 布全体のコンクリートが同 $80^{\circ} \mathrm{C}$ の $840^{\circ} \mathrm{D} \cdot \mathrm{D}$ 時コア供 試体強度ではこの低下率で低下すると仮定すると, 調合 強度は698/ $(1-0.04)-727 \mathrm{kgf} / \mathrm{cm}^{2}$, 水セメント比 $30.4 \%$ となる。

構造体強度管理を $2730^{\circ} \mathrm{D} \cdot \mathrm{D}$ 時標準養生供試体強度 で行う場合では高温履歴の影響を受けない場合は，標準 強度分布で構造体強度管理を行う場合に比べて $9 \%$ 低 くできるとすると, $698 \times 0.91=635 \mathrm{kgf} / \mathrm{cm}^{2}$, 水セメン 卜比約 $30 \%$ である。図一11 より, 平均気温が $28^{\circ} \mathrm{C}$ で は最高到達温度は $70^{\circ} \mathrm{C}$ をずかに超え, そのために調 合強度を上げると同 $73 \sim 4^{\circ} \mathrm{C}$ 位が予想される。図一 $9(\mathrm{~b})$ からそのときコア供試体強度は 0.04/1.11=0.036の低 

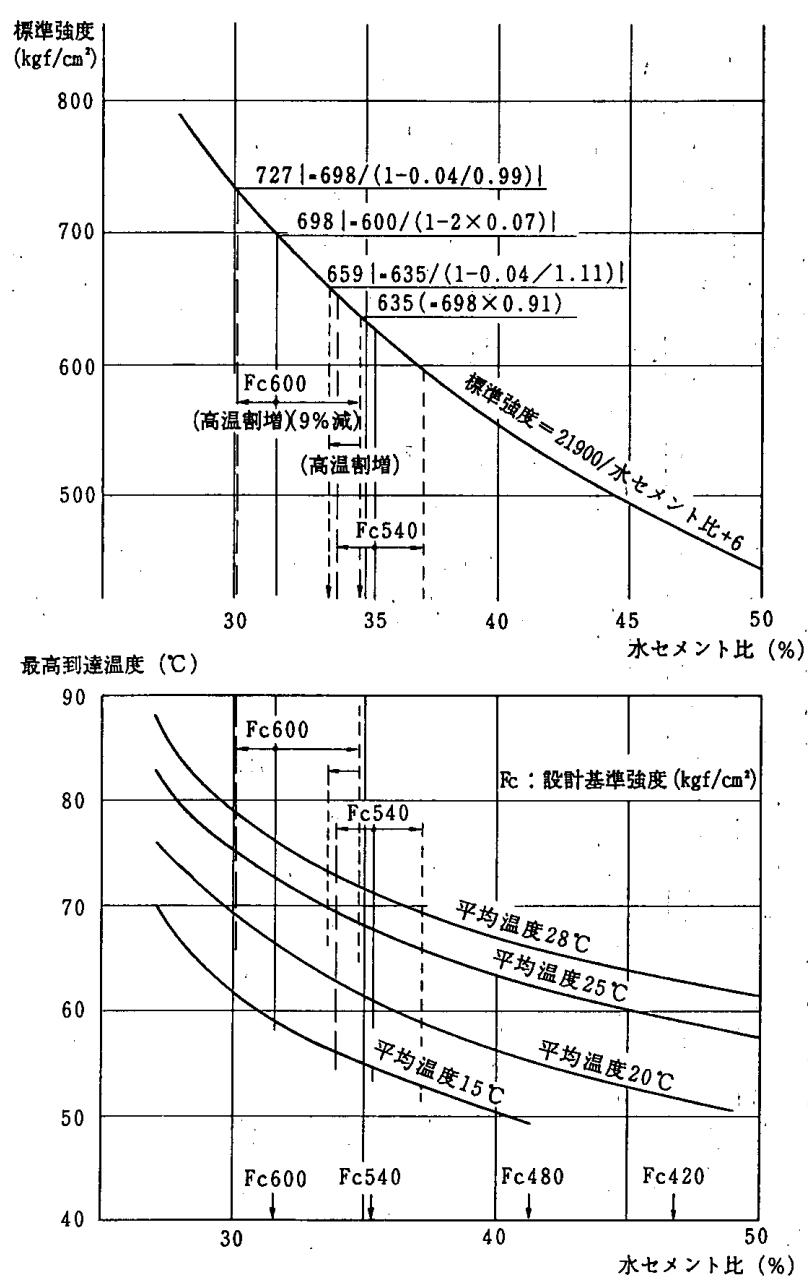

図一11 $1,1 \mathrm{~m} \times 1.1 \mathrm{~m}$ 柱 最高到達温度と調合強度関係図

下率となることが予想されるので，調合強度は $635 /(1$ $-0.036)=659 \mathrm{kgf} / \mathrm{cm}^{2}$, 水セメント比 $33.5 \%$ となる。

同様に, 設計基準強度 $540 \mathrm{kgf} / \mathrm{cm}^{2}$ の場合は図一11 に示すような值になる。設計基準強度 $480 \mathrm{kgf} / \mathrm{cm}^{2}$ 以下 では高温履歴の影響は受けないと見込まれる。図一11 にみるように，構造体強度の発現は水セメント比が小さ いほど高温履歴の影響を大きく受ける。高温履歴を受け て構造体強度が低下する分を補うため, 調合強度の割增 しを行うと，さらに構造体の上昇温度が大きくなって構 造体強度の低下が激しくなる。したがって，設計基準強 度が大きいほざ, 構造体温度の初期の上昇が小さくなる ような調合を計画し，また，“構造体強度の管理材令を長 くする方が有利である。

構造体の初期温度上昇が大きい場合には構造体強度発 現の停滞が起こり，その停滞が起き始める温度として本 論文では最高到達温度 $70^{\circ} \mathrm{C}$ を用いている。これは，表 -4 の結果を主たる根拠にしているが31，正確なその温 度の大きさについては表一 4 のデー夕のみで一般化する のは難しい。最高到達温度に応じた強度発現の期待値も 特定し得るほどではない。現在のところでは，上昇温度 の予測值が $70^{\circ} \mathrm{C}$ 程度以上になるような場合には，実験 によって，その值を個々の工事ごとに確認するのが正確
であると考える。

まとめ

・初期の高温履歴が構造体強度発現に影響を与える項目 として最高到達温度と温度上昇量が考えられるが，最 高到達温度之の関媇のみでも高温履歴之構造体強度発 現の関係のおおよその傾向はとらえられる。

・平均的には設計基準強度 $480 \mathrm{kgf} / \mathrm{cm}^{2}$ 以下の場合に は, 初期の水和発熱による温度上昇は構造体強度発現 に影響を与えないとみなすことができる。

・初期の水和発熱による温度上昇が構造体強度発現に影 響を与えない場合, 構造体強度が設計基準強度を満足 する時期を積算温度 $2730^{\circ} \mathrm{D} \cdot \mathrm{D}$ 時の中長期にとって 調合計画を行うと, $2730^{\circ} \mathrm{D} \cdot \mathrm{D}$ 時コア供試体強度分布 での不良率は標準強度分布で計画した不良率より多少 大きくはなるが，構造体強度が設計基準強度を満足す る時期を $840^{\circ} \mathrm{D} \cdot \mathrm{D}$ 時にして調合計画をしたときに比 べて $9 \%$ 程度調合強度を下げることができる。

・初期の高温履歴の影響を受ける場合, 積算温度 $2730^{\circ}$ $\mathrm{D} \cdot \mathrm{D}$ 時の構造体強度（コア供試体強度）発現は $840^{\circ}$ $\mathrm{D} \cdot \mathrm{D}$ の構造体強度発現に比べて影響が大きく，その 割合は初期の温度上昇が大きいほど激しい。

\section{謝 辞}

本論文に使用している調查, 実験については大成建設 （株）技術研究所黒羽健嗣君, 丸嶋紀夫君, 並木 哲君 および各支店建築部技術室，現場作業所の皆様方のご協 力を得たものである。論文をまとめるにあたっては東京 大学友澤史紀教授のご助言を頂いた。ここに深く感謝致 します。

\section{参考文献}

1） 戸祭邦之，黒羽健嗣：設計基準強度 $360 \mathrm{~kg} / \mathrm{cm}^{2}$ 以上の高 強度コンクリートの調合設計における気温補正について, 日本建築学会構造系論文報告集, 第 419 号, pp. 39 46, 1991 年 1 月

2）戸祭邦之：中長期の強度伸展を考虑した高強度コンク リートの調合計画に関する一考察，日本建築学会構造系 論文報告集，第.429 号，pp. 17 29，1991 年 11月

3）戸祭邦之, 黒羽健嗣, 丸嶋紀夫：水和発熱に上る高温履 歴を初期に受けた高強度コンクリートの強度発現とその 管理についての一考察, 日本建築学会構造系論文報告集, 第 445 号, pp. $1 \sim 10,1993$ 年 3 月

4）戸祭邦之：高強度コンクリートにおける各種養生供試体 強度とコア供試体強度の関係について，日本建築学会構 造系論文報告集，第 449 号，pp. 17 - 30，1993 年 7 月

5） 戸祭邦之：高強度ヨンクリートの強度増進に伴うばらつ きの変化およびその予測について, 日本建築学会構造系 論文報告集，第 428 号，pp. 35 46，1991 年 10 月

(1993 年 9 月 10 日原稿受理, 1994 年 3 月 1 日採用決定） 